\title{
Copper Tolerance and Accumulation on Pelargonium graveolens L'Hér. Grown in Hydroponic Culture
}

\author{
Antonios Chrysargyris ${ }^{1}$, Rita Maggini ${ }^{2}$, Luca Incrocci ${ }^{2}, * \mathbb{D}$, Alberto Pardossi $^{2} \mathbb{D}$ and Nikolaos Tzortzakis ${ }^{1, *} \mathbb{D}$ \\ 1 Department of Agricultural Sciences, Biotechnology and Food Science, Cyprus University of Technology, \\ Limassol 3603, Cyprus; a.chrysargyris@cut.ac.cy \\ 2 Department of Agriculture, Food and Environment, University of Pisa, 56124 Pisa, Italy; \\ rita.maggini@unipi.it (R.M.); alberto.pardossi@unipi.it (A.P.) \\ * Correspondence: luca.incrocci@unipi.it (L.I.); nikolaos.tzortzakis@cut.ac.cy (N.T.)
}

check for updates

Citation: Chrysargyris, A.; Maggini, R.; Incrocci, L.; Pardossi, A.;

Tzortzakis, N. Copper Tolerance and Accumulation on Pelargonium graveolens L'Hér. Grown in Hydroponic Culture. Plants 2021, 10, 1663. https://doi.org/10.3390/ plants10081663

Academic Editors: Ewa Muszyńska, Kinga Dziurka and Mateusz Labudda

Received: 13 July 2021

Accepted: 6 August 2021

Published: 12 August 2021

Publisher's Note: MDPI stays neutral with regard to jurisdictional claims in published maps and institutional affiliations.

Copyright: (C) 2021 by the authors. Licensee MDPI, Basel, Switzerland. This article is an open access article distributed under the terms and conditions of the Creative Commons Attribution (CC BY) license (https:// creativecommons.org/licenses/by/ $4.0 /)$.

\begin{abstract}
Heavy metal contamination is a major health issue concerning the commercial production of medicinal and aromatic plants (MAPs) that are used for the extraction of bioactive molecules. Copper $(\mathrm{Cu})$ is an anthropogenic contaminant that, at toxic levels, can accumulate in plant tissues, affecting plant growth and development. On the other hand, plant response to metal-induced stress may involve the synthesis and accumulation of beneficial secondary metabolites. In this study, hydroponically grown Pelargonium graveolens plants were exposed to different $\mathrm{Cu}$ concentrations in a nutrient solution $(4,25,50,100 \mu \mathrm{M})$ to evaluate the effects $\mathrm{Cu}$ toxicity on plant growth, mineral uptake and distribution in plants, some stress indicators, and the accumulation of bioactive secondary metabolites in leaf tissues. $P$. graveolens resulted in moderately tolerant $\mathrm{Cu}$ toxicity. At $\mathrm{Cu}$ concentrations up to $100 \mu \mathrm{M}$, biomass production was preserved and was accompanied by an increase in phenolics and antioxidant capacity. The metal contaminant was accumulated mainly in the roots. The leaf tissues of Cu-treated P. graveolens may be safely used for the extraction of bioactive molecules.
\end{abstract}

Keywords: antioxidants; bioaccumulation; copper toxicity; hydroponics; translocation factor

\section{Introduction}

Copper $(\mathrm{Cu})$ is an abundant transition metal of the lithosphere that is considered a relevant anthropogenic contaminant, as large amounts of this element have been released into the environment over the past decades [1,2]. In addition to the environmental impact of mining and smelting operations, the extensive application of $\mathrm{Cu}$-containing fertilizers, pesticides and fungicides in agricultural practices has contributed to water body and soil contamination [1-4]; therefore, agricultural soils are particularly exposed to pollution by this contaminant. For example, Chen et al. [5] reported that in China, over 16\% of agricultural soil is contaminated by heavy metals, and $2 \%$ is polluted by $\mathrm{Cu}$ only. Among heavy metals, $\mathrm{Cu}$ is often the only contaminant in vineyards, where it is extensively used against downy mildew [1-4]. According to the European Council Directive 86/278/EEC [6] on the protection of the environment, the permitted $\mathrm{Cu}$ concentration in agricultural soils amended with sewage sludge is $50-140 \mathrm{mg} \mathrm{kg}^{-1}$ for $\mathrm{pH}$ values in the range 6-7. For uncontaminated soils, Kabata-Pendias and Szteke [7] indicated a $\mathrm{Cu}$ concentration range of $1-140 \mathrm{mg} \mathrm{kg}^{-1}$, depending on soil texture; the same authors reported that soil $\mathrm{Cu}$ concentrations in the range $25-40 \mathrm{mg} \mathrm{kg}^{-1}$ may be toxic to plants below $\mathrm{pH} 5.5$, as $\mathrm{Cu}$ availability increases with soil acidity.

In nature, $\mathrm{Cu}$ commonly exists in the elemental metal form or as $\mathrm{Cu}^{+}$or $\mathrm{Cu}^{2+}$ ions, although the oxidation states +3 and +4 can also be found [8]. Due to its redox properties, $\mathrm{Cu}$ at low concentration has a fundamental biological role for all living organisms, taking part in several metabolic reactions $[9,10]$. In higher plants, $\mathrm{Cu}$ is an essential micronutrient that is necessary for normal growth and development [11], being involved in mineral nutrition and electron transfer reactions that occur in vital processes, such as respiration 
and photosynthesis, chlorophyll and primary metabolites biosynthesis, or the scavenging of radicals [4]. The $\mathrm{Cu}$ concentration range that is considered normal for plants ranges from 2-5 to $30 \mathrm{mg} \mathrm{kg}^{-1}$ dry weight (DW) [12,13], while at higher concentrations Cu can cause toxicity symptoms [14]. Toxic levels of $\mathrm{Cu}$ in plants can impair biochemical reactions, affect gas exchanges, reduce plant growth $[15,16]$. Plants grown in $\mathrm{Cu}$-polluted soils undergo oxidative stress and accumulate reactive oxygen species (ROS) [17], which induces the activation of antioxidant enzymes and the biosynthesis of antioxidant molecules. Cu toxicity has also been associated with an increased content of proline in plant tissues [18,19].

To counteract the effects of metal toxicity, plants have developed tolerance mechanisms such as metal complexation, storage in vacuoles, precipitation in cell walls, and downregulation of metal transporters via the plasma membrane $[20,21]$. On the other hand, plant species capable of effectively up taking heavy metals from the soil and accumulating these contaminants in tissues generally show a high translocation rate from roots to shoots. These species can be profitably used for phytoremediation through the removal of toxic metals from the soil, which represents a green and cost-effective strategy for the amelioration of marginal lands [22,23]. According to recent literature [2], about 500 species are currently used for the phytoremediation of metal polluted soils. Conversely, the accumulation of toxic metals by plant species that are employed for human usage represents a serious threat for the consumers safety and has become a health concern worldwide. Medicinal and aromatic plants (MAPs) are typically used in the food, pharmaceutical and cosmetic industries as a natural source of biologically active compounds [24], and are increasingly cultivated on a commercial scale to sustain the expansion of the market demand. Contamination of the plant material is a major health issue concerning the commercial production of MAPs [25]. On the other hand, the physiological markers of plant response to metal-induced stress are often beneficial bioactive secondary metabolites, mainly antioxidants such as phenolic compounds or essential oils constituents [26-29].

The Pelargonium genus in the family Geraniaceae comprises several hundreds of aromatic species, distributed worldwide in subtropical and temperate regions [30]. The essential oil from Pelargonium spp. is among the top 20 essential oils used all over the world [31] due to its well-known bioactive properties [32-34]. In addition, the pharmacological activity of Pelargonium spp. is attributed also to phenolic constituents such as flavonoids and hydroxycinnamic acid-derivatives [35]. Pelargomium spp. are tolerant to toxicity by heavy metals and have been successfully applied as hyperaccumulators for several metal contaminants [36], including Cu [37]. Particularly, Pelargomium graveolens L'Hér., popularly known as rose-scented geranium, has been reported by several authors as a good candidate for phytoremediation; in addition, the effect of heavy metals on the yield and quality of its essential oil has been widely investigated [38-40]. However, in recent years the pharmacological activity of $P$. graveolens has been increasingly linked also to the leaf content and composition of the pool of antioxidant phenolics [27,41-44], and much less is known about the influence of heavy metals on the concentration of these compounds. Therefore, the aim of the present study was to verify the tolerance of $P$. graveolens to $\mathrm{Cu}$ toxicity and to test the hypothesis that $\mathrm{Cu}$-induced stress could stimulate the synthesis of antioxidant phenolic constituents, thus improving the medicinal properties of this species. With these objectives, we evaluated the effects of $\mathrm{Cu}$ exposure in $P$. graveolens, in terms of metal translocation to different plant organs, plant growth, and synthesis of bioactive phenolic metabolites.

\section{Results}

\subsection{Visible Injury and Plant Growth}

The plants appeared healthy during the whole growing cycle. Typical toxicity symptoms, such as leaf chlorosis and necrosis, were not observed in Cu-treated plants. Two-way ANOVA revealed that sampling date (D) significantly $(p<0.05 ; p<0.001)$ affected the number of leaves produced and total upper fresh biomass, while neither $\mathrm{Cu}$ nor the interaction of date $\times \mathrm{Cu}(\mathrm{D} \times \mathrm{Cu})$ affected the plant height, leaf number and total upper fresh biomass 
and dry matter content (Table 1). Copper concentration in the nutrient solution affected pelargonium growth parameters (Table 1). Plants grown with $\geq 25 \mu \mathrm{M} \mathrm{Cu}$ in the nutrient solution produced lower number of leaves at 35 DAT (days after transplanting), but this effect did not persist at 49 DAT. Total upper fresh biomass (including leaves, petioles and stems) decreased at the highest $\mathrm{Cu}(100 \mu \mathrm{M} \mathrm{Cu})$ levels compared with the plants grown at $25 \mu \mathrm{M}$ or $50 \mu \mathrm{M} \mathrm{Cu}$ after 35 DAT. Dry matter content at 49 DAT increased in plants grown in $\geq 50 \mu \mathrm{M} \mathrm{Cu}$ compared to $25 \mu \mathrm{M} \mathrm{Cu}$ and control treatment.

Table 1. Effect of increasing copper $(\mathrm{Cu})$ concentration $\left(4-25-50-100 \mu \mathrm{M} \mathrm{Cu}^{+2}\right)$ in the nutrient solution and sampling date after transplanting (DAT, 35 days and 49 days) on plant height $(\mathrm{cm})$, leaf number, total upper fresh biomass $\left(\mathrm{g}\right.$ plant $\left.{ }^{-1}\right)$, and biomass dry matter content (\%) in pelargonium plants grown hydroponically in perlite.

\begin{tabular}{|c|c|c|c|c|c|}
\hline DAT & $\mathrm{Cu}^{2+}(\mu \mathrm{M})$ & $\begin{array}{l}\text { Plant } \\
\text { Height }\end{array}$ & $\begin{array}{c}\text { Leaf } \\
\text { Number }\end{array}$ & $\begin{array}{c}\text { Total Upper } \\
\text { Fresh Biomass }\end{array}$ & $\begin{array}{l}\text { Total Upper Biomass } \\
\text { Dry Matter Content }\end{array}$ \\
\hline \multirow[t]{4}{*}{35 days } & 4 & $43.16 \pm 2.19^{Y}$ & $32.50 \pm 4.66 \mathrm{a}$ & $57.14 \pm 3.78 \mathrm{ab}$ & $12.19 \pm 0.48$ \\
\hline & 25 & $44.33 \pm 1.72$ & $24.66 \pm 1.17 \mathrm{~b}$ & $68.39 \pm 2.75 a$ & $12.19 \pm 0.28$ \\
\hline & 50 & $42.33 \pm 2.67$ & $25.50 \pm 3.52 b$ & $70.02 \pm 4.69 \mathrm{a}$ & $12.16 \pm 0.91$ \\
\hline & 100 & $42.83 \pm 2.15$ & $22.33 \pm 2.84 \mathrm{~b}$ & $50.72 \pm 6.10 \mathrm{~b}$ & $13.16 \pm 0.91$ \\
\hline \multirow[t]{4}{*}{49 days } & 4 & $53.00 \pm 4.57$ & $58.00 \pm 6.29$ & $160.04 \pm 0.80$ & $12.89 \pm 0.07 \mathrm{~b}$ \\
\hline & 25 & $50.00 \pm 5.19$ & $41.83 \pm 6.87$ & $152.92 \pm 21.32$ & $12.68 \pm 0.15 b$ \\
\hline & 50 & $54.83 \pm 9.22$ & $42.33 \pm 8.36$ & $156.89 \pm 10.77$ & $13.77 \pm 0.08 \mathrm{a}$ \\
\hline & 100 & $56.40 \pm 2.22$ & $52.80 \pm 4.66$ & $133.55 \pm 20.87$ & $13.72 \pm 0.19 \mathrm{a}$ \\
\hline \multicolumn{6}{|c|}{ Significance } \\
\hline \multicolumn{2}{|c|}{ Days (D) } & $n s$ & * & $* * *$ & $n s$ \\
\hline \multicolumn{2}{|c|}{ Copper $(C u)$} & ns & ns & $n s$ & $n s$ \\
\hline \multicolumn{2}{|c|}{$D x C u$} & ns & ns & ns & $n s$ \\
\hline
\end{tabular}

${ }^{Y}$ At each sampling date, values $(n=6)$ in columns followed by different letters are significantly different, $p<0.05$, for each plant growth stage. $n s,{ }^{*}$ and ${ }^{* * *}$ indicate non-significant or significant differences at $p<5 \%$, and $0.1 \%$, respectively, following two-way ANOVA.

Looking at the fresh and dry biomass of individual plant organs, it was found that leaves and stems were increased at 35 DAT at $25-50 \mu \mathrm{M} \mathrm{Cu}$ compared to $100 \mu \mathrm{M} \mathrm{Cu}$ (Figure 1). Petiole fresh weight (FW) was also increased at 25-50 $\mu \mathrm{M}$ Cu compared with control or $100 \mu \mathrm{M} \mathrm{Cu}$. Copper levels did not affect the root FW at 35 DAT. Following 49 DAT, leaf, stem, petiole and root FW were at similar levels (averages of 64.24, 26.13, 60.48 and $14.44 \mathrm{~g}$, respectively), independent of the $\mathrm{Cu}$ concentration in the nutrient solution. Petiole dry matter content increased in $25-50 \mu \mathrm{M} \mathrm{Cu}$, compared to the control treatment at 35 DAT. However, root dry matter content increased in $100 \mu \mathrm{M} \mathrm{Cu}$ compared to $25 \mu \mathrm{M} \mathrm{Cu}$ at 49 DAT.

\subsection{Effects on Plant Physiology Attributes}

Plants grown at the high $\mathrm{Cu}$ concentration of $100 \mu \mathrm{M} \mathrm{Cu}$ revealed higher stomatal resistance at both 35 and 49 DAT, compared to the control treatment (Table 2). Contrarily, chlorophyll fluorescence as measured by Fv/Fm (representing the maximum quantum yield of PSII), decreased at $100 \mu \mathrm{M} \mathrm{Cu}$ when compared to control and/or $25 \mu \mathrm{M} \mathrm{Cu}$ at 35 DAT and 49 DAT. The content of chlorophylls, as measured by chlorophyll a, chlorophyll $\mathrm{b}$ and total chlorophylls, did not change among the treatments at 35 DAT, but decreased at higher $\mathrm{Cu}$ levels (i.e., $100 \mu \mathrm{M} \mathrm{Cu}$ ) at 49 DAT compared to the control and/or $25 \mu \mathrm{M} \mathrm{Cu}$.

Two-way ANOVA revealed that sampling date (D) significantly affected stomatal conductivity and chlorophyll fluorescence $(p<0.001)$; copper levels significantly affected stomatal conductance and chlorophyll a $(p<0.05)$, while the interaction of sampling date and copper $(\mathrm{D} \times \mathrm{Cu})$ did not affect the examined physiological parameters (Table 2). 

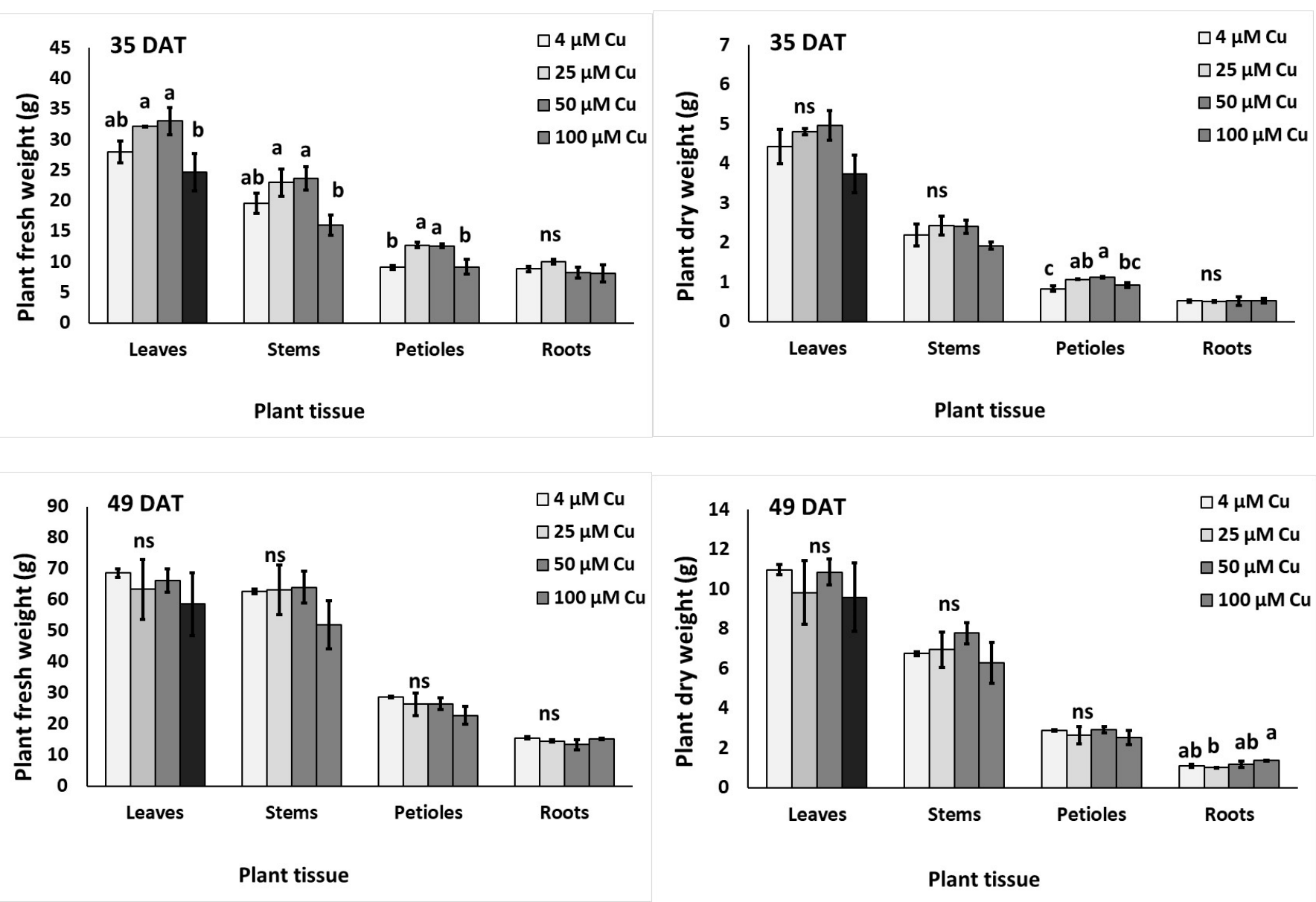

Figure 1. Effect of increasing copper $(\mathrm{Cu})$ concentration $\left(4-25-50-100 \mu \mathrm{M} \mathrm{Cu}^{2+}\right)$ in the nutrient solution and sampling date after transplanting (DAT, 35 days and 49 days) on the fresh (FW; g plant ${ }^{-1}$ ) and dry weight (DW; g plant ${ }^{-1}$ ) of leaves, stems, petioles and roots respectively, of pelargonium plants grown hydroponically in perlite. Significant differences $(p<0.05)$ among $\mathrm{Cu}$ concentrations for each plant tissue are indicated by different letters; ns indicates non-significant. Error bars show SE $(n=6)$.

\subsection{Effects on Total Phenols, Flavonoids and Antioxidant Activity}

Two-way ANOVA revealed that sampling dates (35 vs. 49 DAT) significantly effected total phenols and DPPH (2,2-diphenyl-1-picrylhydrazyl) $(p<0.01)$, Cu levels significantly effected ABTS (2,2'-azino-bis(3-ethylbenzothiazoline-6-sulphonic acid) $(p<0.05)$ and flavonoids $(p<0.01)$, while the interaction of the sampling date $\times$ Cu effected ABTS and flavonoids $(p<0.05)$ and total phenolics $(p<0.01)$. The content of flavonoids and antioxidant activity (as assayed by ferric reducing antioxidant power; FRAP, DPPH, ABTS) revealed their highest values at $50 \mu \mathrm{M} \mathrm{Cu}$, when compared with control and $100 \mu \mathrm{M}$ of $\mathrm{Cu}$, and differed significantly also from $25 \mu \mathrm{M} \mathrm{Cu}$ in the case of flavonoids and DPPH at 35 DAT (Figure 2). The content of total phenols and flavonoids, as well as antioxidant activity as assayed by FRAP and ABTS, revealed an increased trend as the $\mathrm{Cu}$ level increased at $49 \mathrm{DAT}$, with significant differences at the high $\mathrm{Cu}$ levels compared to the control treatment (Figure 2A-C,E). 
Table 2. Effect of increasing copper $(\mathrm{Cu})$ concentration $\left(4-25-50-100 \mu \mathrm{M} \mathrm{Cu}^{2+}\right)$ in the nutrient solution and sampling date after transplanting-DAT (35 days and 49 days) on leaf stomatal resistance $\left(\mathrm{cm} \mathrm{s}^{-1}\right)$, chlorophyll fluorescence (Fv/Fm), chlorophylls (Chl a, Chl b, Total Chl) content ( $\mathrm{g} \mathrm{g} \mathrm{g}^{-1}$ fresh weight) in pelargonium plants grown hydroponically in perlite.

\begin{tabular}{|c|c|c|c|c|c|c|}
\hline DAT & $\mathrm{Cu}^{2+}(\mu \mathrm{M})$ & Stomatal Resistance & Fv/Fm & Chl a & Chl b & Total Chl \\
\hline \multirow[t]{4}{*}{35 days } & 4 & $0.90 \pm 0.13 b^{Y}$ & $0.83 \pm 0.003 \mathrm{a}$ & $23.47 \pm 0.35$ & $36.32 \pm 0.77$ & $59.77 \pm 1.04$ \\
\hline & 25 & $1.33 \pm 0.08 \mathrm{ab}$ & $0.83 \pm 0.001 \mathrm{a}$ & $23.80 \pm 2.21$ & $35.12 \pm 2.57$ & $58.90 \pm 4.77$ \\
\hline & 50 & $1.34 \pm 0.15 \mathrm{ab}$ & $0.83 \pm 0.050 \mathrm{ab}$ & $23.97 \pm 0.39$ & $35.59 \pm 0.71$ & $59.54 \pm 0.83$ \\
\hline & 100 & $1.61 \pm 0.19 \mathrm{a}$ & $0.82 \pm 0.003 \mathrm{~b}$ & $23.49 \pm 2.57$ & $34.56 \pm 2.15$ & $58.03 \pm 5.72$ \\
\hline \multirow[t]{4}{*}{49 days } & 4 & $6.75 \pm 0.50 \mathrm{~b}$ & $0.80 \pm 0.006 \mathrm{a}$ & $28.14 \pm 1.10 \mathrm{a}$ & $39.76 \pm 0.96 a$ & $66.55 \pm 1.39 \mathrm{a}$ \\
\hline & 25 & $9.11 \pm 1.20 \mathrm{ab}$ & $0.78 \pm 0.005 \mathrm{ab}$ & $26.81 \pm 0.43 \mathrm{ab}$ & $36.62 \pm 0.14 \mathrm{ab}$ & $66.81 \pm 2.60 \mathrm{a}$ \\
\hline & 50 & $9.05 \pm 0.78 \mathrm{ab}$ & $0.78 \pm 0.007 \mathrm{ab}$ & $24.79 \pm 0.85 b$ & $38.68 \pm 1.52 \mathrm{ab}$ & $66.81 \pm 2.60 \mathrm{ab}$ \\
\hline & 100 & $10.58 \pm 1.38 \mathrm{a}$ & $0.75 \pm 0.019 \mathrm{~b}$ & $21.46 \pm 0.91 c$ & $35.22 \pm 1.30 \mathrm{~b}$ & $56.66 \pm 2.17 b$ \\
\hline \multicolumn{7}{|c|}{ Significance } \\
\hline \multicolumn{2}{|c|}{ Days (D) } & $* * *$ & $* * *$ & $n s$ & $n s$ & $n s$ \\
\hline \multicolumn{2}{|c|}{ Copper $(\mathrm{Cu})$} & * & $n s$ & $*$ & $n s$ & $n s$ \\
\hline \multicolumn{2}{|c|}{$D x C u$} & $n s$ & $n s$ & $n s$ & $n s$ & $n s$ \\
\hline
\end{tabular}

${ }^{\mathrm{Y}}$ At each sampling date, values $(n=6)$ in columns followed by different letters are significantly different, $p<0.05$, for each plant growth stage. $n s, *$ and $* * *$ indicate non-significant or significant differences at $p<5 \%$, and $0.1 \%$, respectively, following two-way ANOVA.

\subsection{Plant Stress Indices}

Two-way ANOVA revealed that sampling dates (35 vs. 49 DAT), $\mathrm{Cu}$ levels and their interactions significantly affected hydrogen peroxide $\left(\mathrm{H}_{2} \mathrm{O}_{2}\right)$ and malondialdehyde (MDA) levels $(p<0.01, p<0.001)$. Hydrogen peroxide levels increased at $25 \mu \mathrm{M} \mathrm{Cu}$ in comparison to the 50-100 $\mu \mathrm{M} \mathrm{Cu}$, but did not differ from the control at 35 DAT (Figure 3A). Following $49 \mathrm{DAT}, \mathrm{H}_{2} \mathrm{O}_{2}$ increased at $100 \mu \mathrm{M} \mathrm{Cu}$ compared to lower $\mathrm{Cu}$ levels and/or control. Lipid peroxidation (as assayed by MDA) increased at $50 \mu \mathrm{M} \mathrm{Cu}$ in comparison to higher or lower $\mathrm{Cu}$ levels at $35 \mathrm{DAT}$, while MDA decreased with $\geq 25 \mu \mathrm{M} \mathrm{Cu}$ compared to the control treatment (at $4 \mu \mathrm{M} \mathrm{Cu}$ ) at 49 DAT (Figure 3B).

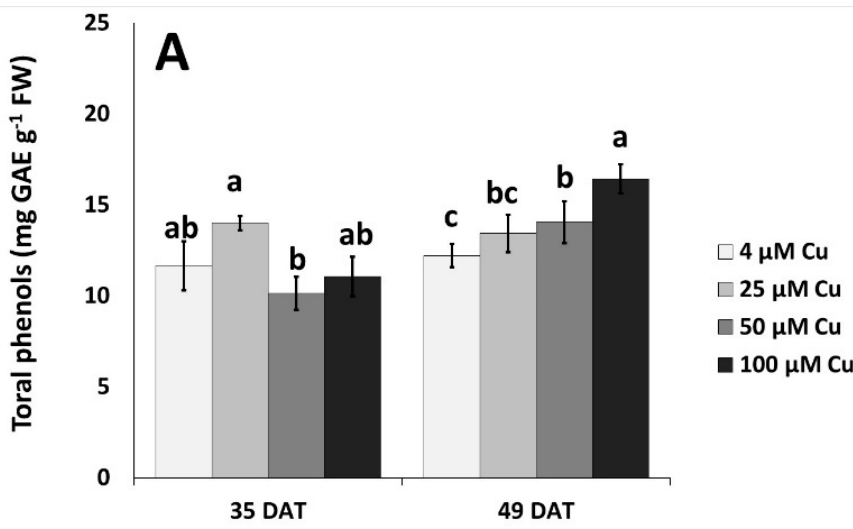

Days after transplanting

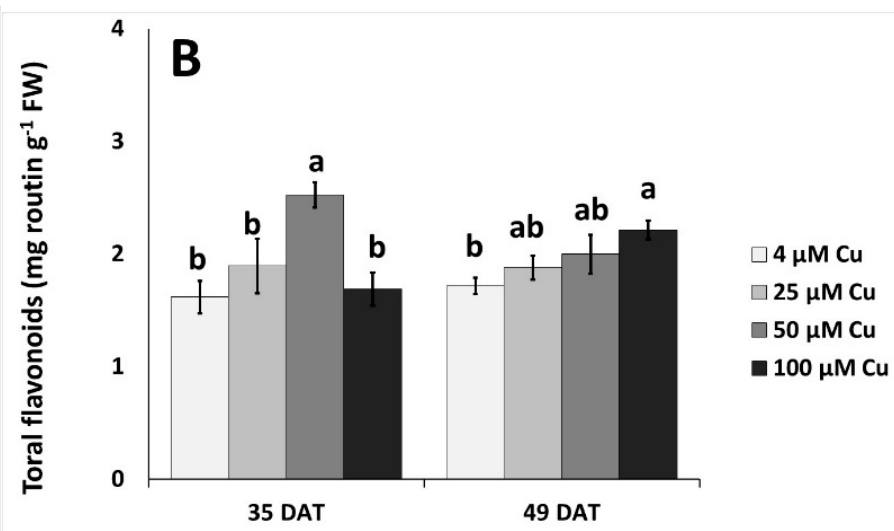

Days after transplanting

Figure 2. Cont. 


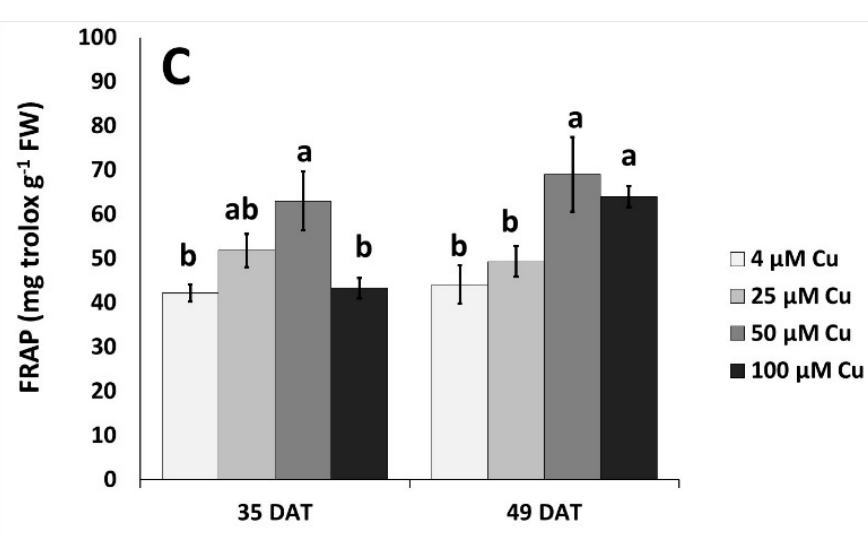

Days after transplanting

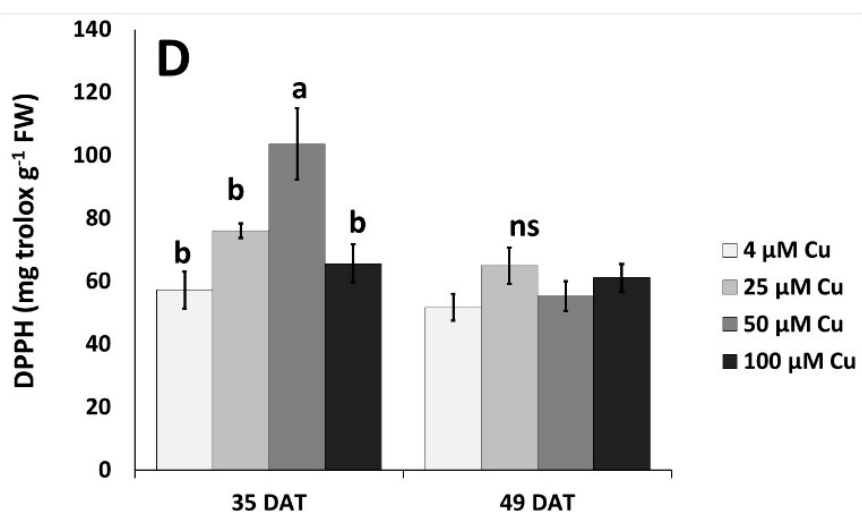

Days after transplanting

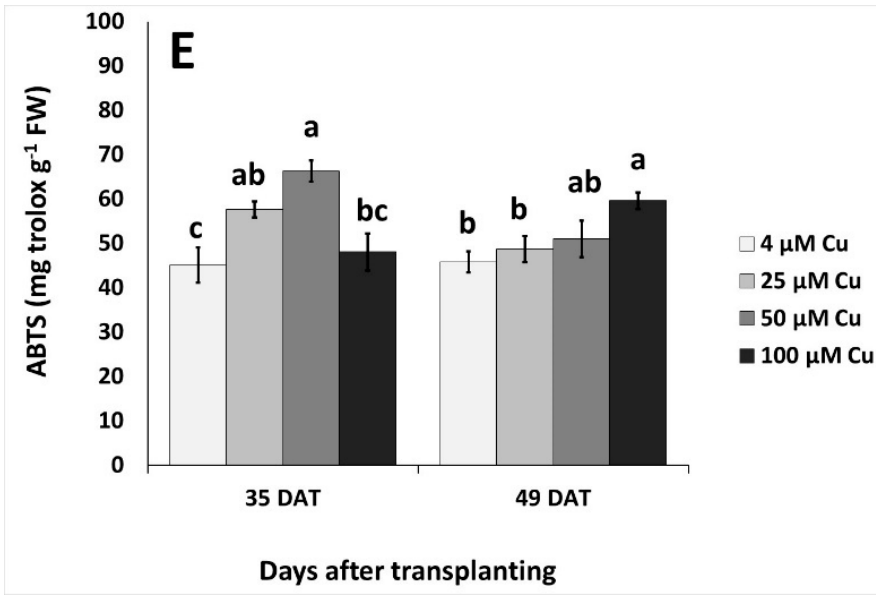

Figure 2. Effect of increasing copper $(\mathrm{Cu})$ concentration $\left(4-25-50-100 \mu \mathrm{M} \mathrm{Cu}^{2+}\right)$ in the nutrient solution and sampling date after transplanting (DAT, 35 days and 49 days) on the leaf content of total phenols, total flavonoids and antioxidant activity in pelargonium plants grown hydroponically in perlite. (A) Total phenols, (B) total flavonoids, (C) FRAP (D) DPPH, and $(\mathrm{E})$ ABTS. Significant differences $(p<0.05)$ among $\mathrm{Cu}$ concentrations at each sampling date are indicated by different letters; ns indicates non-significant. Error bars show SE $(n=4)$.
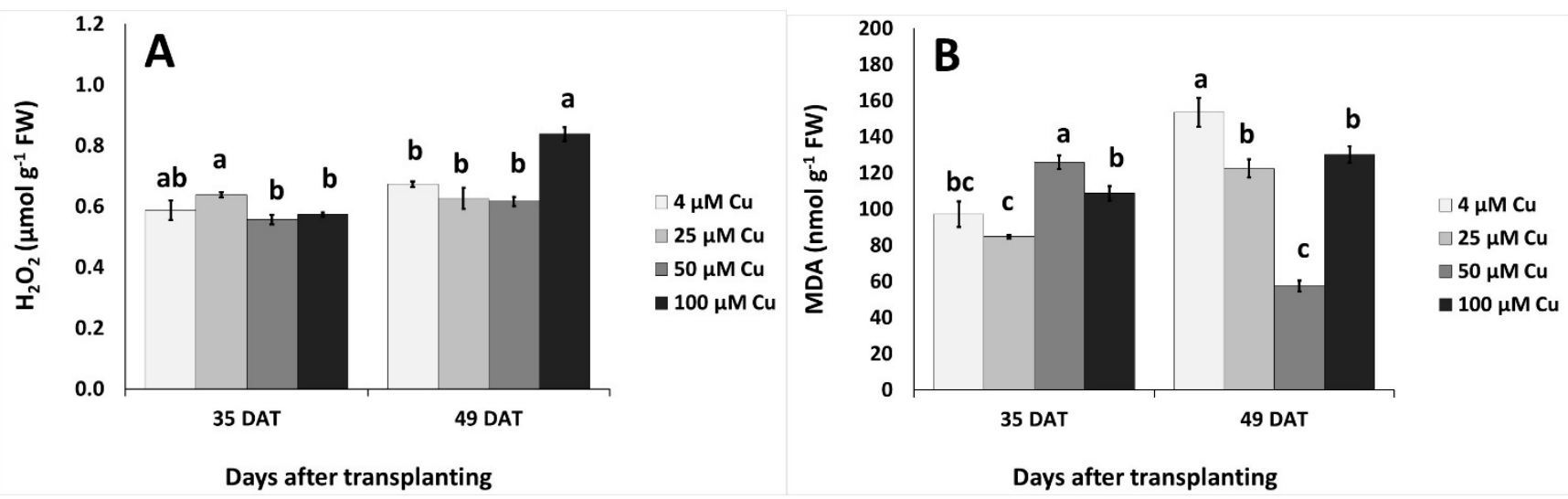

Figure 3. Effect of increasing copper $(\mathrm{Cu})$ concentration $\left(4-25-50-100 \mu \mathrm{M} \mathrm{Cu}^{2+}\right)$ in the nutrient solution and sampling date after transplanting (DAT, 35 days and 49 days) on the leaf content of hydrogen peroxide $\left(\mathrm{H}_{2} \mathrm{O}_{2} ;(\mathbf{A})\right)$ and malondialdehyde (MDA; (B)) in pelargonium plants grown hydroponically in perlite. Significant differences $(p<0.05)$ among Cu concentrations at each sampling date are indicated by different letters. Error bars show SE $(n=4)$. 


\subsection{Copper Content in Plant Tissues}

Two-way ANOVA revealed that sampling date (D) significantly affected AR, BACroots, BAC-stems, TF-leaves, TF-stems, TF-petioles $(p<0.001)$, and BAC-petioles $(p<0.05)$; $\mathrm{Cu}$ levels significantly affected BAC-roots, BAC-leaves, BAC-stems, BAC-petioles, TFleaves, TF-stems, and TF-petioles $(p<0.001)$, while the interaction of sampling date and $\mathrm{Cu}(\mathrm{D} \times \mathrm{Cu})$ affected BAC-roots, BAC-stems, BAC-petioles, TF-leaves, TF-stems and TFpetioles $(p<0.001)$ (Table 3). The copper accumulation rate increased at $50 \mu \mathrm{M}$ of $\mathrm{Cu}$ compared with the control at 35 DAT. All bioaccumulation coefficients and translocation factors for leaves, stems, petioles and roots were significantly decreased with $\geq 25 \mu \mathrm{M}$ of $\mathrm{Cu}$ in the nutrient solution at 35 and 49 DAT (Table 3).

Regarding tolerance index, two-way ANOVA revealed that sampling date (D) significantly affected TI-petiole FW and TI-petiole DW $(p<0.001)$; copper levels significantly affected TI-total biomass, TI-stem FW and TI-petiole FW $(p<0.05)$; while the interaction of sampling date and $\mathrm{Cu}(\mathrm{D} \times \mathrm{Cu})$ affected only the TI-petiole FW $(p<0.05)($ Table 4$)$. Tolerance index values of plant growth were affected at $35 \mathrm{DAT}$, as TI increased at 25-50 $\mu \mathrm{M}$ $\mathrm{Cu}$ for leaf, stem and petiole FW and as a consequence of the plant total biomass when compared with $100 \mu \mathrm{M} \mathrm{Cu}$ in the nutrient solution (Table 4). Similarly, TI-leaf DW and TI-petiole DW were also increased at 20-50 $\mu \mathrm{M} \mathrm{Cu}$. The TI of leaf number was decreased with $\geq 25 \mu \mathrm{M} \mathrm{Cu}$ in the nutrient solution at 35 DAT. At 49 DAT, the TI for total biomass was increased with $25 \mu \mathrm{M} \mathrm{Cu}$ in the nutrient solution, while TI-root DW increased at $100 \mu \mathrm{M}$ $\mathrm{Cu}$ when compared to $\leq 25 \mu \mathrm{M} \mathrm{Cu}$ (Table 4 ).

\subsection{Responses of Other Nutrients}

The accumulation of nutrients in different plant organs (leaves, stems, petioles and roots) under different $\mathrm{Cu}$ levels at two sampling periods (35 and 49 DAT) is described in Figures 4 and 5. At $35 \mathrm{DAT}$, the leaf content of $\mathrm{N}$ and $\mathrm{K}$ increased in $25 \mu \mathrm{M} \mathrm{Cu}$ and decreased or remained unaffected in $\geq 50 \mu \mathrm{M} \mathrm{Cu}$ compared to the control (Figure $4 \mathrm{~A}, \mathrm{C}$ ). Stem N decreased at $100 \mu \mathrm{M} \mathrm{Cu}$ when compared with $25 \mu \mathrm{M} \mathrm{Cu}$, however the $\mathrm{N}$ level in petioles and roots remained similar in plants grown with different $\mathrm{Cu}$ levels in the nutrient solution (Figure 4A). Leaf and stem $\mathrm{N}$ levels were similar at $49 \mathrm{DAT}$ in all examined $\mathrm{Cu}$ levels in the nutrient solution (Figure 4B). Petiole $\mathrm{K}$ increased in $25-50 \mu \mathrm{M} \mathrm{Cu}$ compared to the control (Figure 4C). Phosphorus content in leaves, stems and petioles was unaffected by the $\mathrm{Cu}$ levels in the nutrient solution, while $\mathrm{P}$ in roots decreased at $50 \mu \mathrm{M} \mathrm{Cu}$ and increased at $100 \mu \mathrm{M} \mathrm{Cu}$ compared to the control treatment (Figure 4E). Increased P levels were found at $49 \mathrm{DAT}$ in roots at $50 \mu \mathrm{M} \mathrm{Cu}$ (Figure $4 \mathrm{~F}$ ). Sodium accumulated more in petioles, compared to leaves, stems and roots, while $\mathrm{Na}$ content decreased at high $\mathrm{Cu}$ levels (Figure 4G,H).

Copper accumulated in stems, petioles and roots as the $\mathrm{Cu}$ concentration increased in the nutrient solution; at $35 \mathrm{DAT}$, greater effects were observed in roots (2.2-fold increase at $100 \mu \mathrm{M} \mathrm{Cu}$ compared to the control treatment) (Figure 5A). A similar trend was found in $\mathrm{Cu}$ accumulation even at 49 DAT, but the increment in roots at $50-100 \mu \mathrm{M} \mathrm{Cu}$ was 6.9-fold greater compared with the control treatment (Figure 5B). Zinc accumulated more in leaves, stems, and petioles at $35 \mathrm{DAT}$ as $\mathrm{Cu}$ levels increased in the nutrient solution, whereas $\mathrm{Zn}$ content decreased in roots with increasing $\mathrm{Cu}$ concentration in the nutrient solution (Figure 5C). However, the reverse was evidenced at $49 \mathrm{DAT}$, as $\mathrm{Zn}$ accumulated in roots following increases of $\mathrm{Cu}$ levels in the nutrient solution (Figure 5D). 


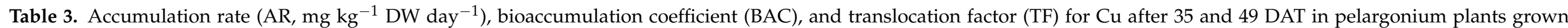
hydroponically in perlite.

\begin{tabular}{|c|c|c|c|c|c|c|c|c|c|}
\hline \multirow{2}{*}{ DAT } & \multirow{2}{*}{$\begin{array}{l}\mathrm{Cu}^{2+} \\
(\mu \mathrm{M})\end{array}$} & \multirow{2}{*}{$\begin{array}{c}\text { Accumulation Rate-AR } \\
\left(\mathrm{mg} \mathrm{kg}^{-1} \mathrm{DW} \text { day }^{-1}\right)\end{array}$} & \multicolumn{4}{|c|}{ Bioaccumulation Coefficient (BAC) } & \multicolumn{3}{|c|}{ Translocation Factor (TF) } \\
\hline & & & Leaves & Stems & Petioles & Roots & Leaves & Stems & Petioles \\
\hline \multirow[t]{4}{*}{35 days } & 4 & $94.94 \pm 18.78 \mathrm{~b}^{\mathrm{Y}}$ & $140.66 \pm 13.50 \mathrm{a}$ & $124.48 \pm 4.71 \mathrm{a}$ & $104.66 \pm 1.17 \mathrm{a}$ & $575.99 \pm 90.69 a$ & $0.25 \pm 0.03 \mathrm{a}$ & $0.22 \pm 0.03 \mathrm{a}$ & $0.19 \pm 0.03 a$ \\
\hline & 25 & $145.97 \pm 9.78 \mathrm{ab}$ & $24.03 \pm 0.66 b$ & $21.66 \pm 0.64 \mathrm{~b}$ & $19.34 \pm 0.45 b$ & $193.77 \pm 15.76 b$ & $0.12 \pm 0.01 \mathrm{~b}$ & $0.11 \pm 0.01 \mathrm{~b}$ & $0.10 \pm 0.01 b$ \\
\hline & 50 & $165.14 \pm 30.56 \mathrm{a}$ & $12.40 \pm 0.14 \mathrm{~b}$ & $11.49 \pm 0.41 c$ & $11.89 \pm 0.24 \mathrm{c}$ & $84.51 \pm 14.58 \mathrm{~b}$ & $0.15 \pm 0.03 \mathrm{~b}$ & $0.14 \pm 0.02 b$ & $0.11 \pm 0.03 \mathrm{~b}$ \\
\hline & 100 & $124.05 \pm 12.80 \mathrm{ab}$ & $6.27 \pm 0.14 b$ & $5.89 \pm 0.11 c$ & $6.67 \pm 0.13 \mathrm{~d}$ & $73.67 \pm 6.63 \mathrm{~b}$ & $0.08 \pm 0.01 b$ & $0.08 \pm 0.00 \mathrm{~b}$ & $0.09 \pm 0.01 \mathrm{~b}$ \\
\hline \multirow[t]{4}{*}{49 days } & 4 & $549.13 \pm 23.12$ & $133.81 \pm 6.98 \mathrm{a}$ & $104.82 \pm 2.14 \mathrm{a}$ & $124.29 \pm 6.70 \mathrm{a}$ & $212.23 \pm 3.35 \mathrm{a}$ & $0.63 \pm 0.02 \mathrm{a}$ & $0.49 \pm 0.00 \mathrm{a}$ & $0.58 \pm 0.03 a$ \\
\hline & 25 & $676.26 \pm 170.78$ & $23.60 \pm 0.71 b$ & $18.66 \pm 2.62 b$ & $19.89 \pm 0.66 b$ & $137.88 \pm 4.70 \mathrm{~b}$ & $0.17 \pm 0.01 b$ & $0.13 \pm 0.02 b$ & $0.14 \pm 0.00 \mathrm{~b}$ \\
\hline & 50 & $965.19 \pm 42.52$ & $11.31 \pm 0.72 c$ & $9.96 \pm 0.77 c$ & $8.58 \pm 0.62 c$ & $124.42 \pm 21.48 b$ & $0.09 \pm 0.02 c$ & $0.08 \pm 0.01 \mathrm{c}$ & $0.07 \pm 0.01 \mathrm{c}$ \\
\hline & 100 & $955.28 \pm 260.27$ & $6.01 \pm 0.35 c$ & $6.49 \pm 0.45 c$ & $4.37 \pm 0.06 \mathrm{c}$ & $67.25 \pm 0.92 c$ & $0.09 \pm 0.00 c$ & $0.09 \pm 0.01 \mathrm{c}$ & $0.06 \pm 0.00 \mathrm{c}$ \\
\hline \multicolumn{10}{|c|}{ Significance } \\
\hline \multicolumn{2}{|c|}{ Days (D) } & $* * *$ & $n s$ & $* * *$ & * & $* * *$ & $* * *$ & $* * *$ & $* * *$ \\
\hline \multicolumn{2}{|c|}{ Copper $(\mathrm{Cu})$} & ns & $* * *$ & $* * *$ & $* * *$ & $* * *$ & $* * *$ & $* * *$ & $* * *$ \\
\hline \multicolumn{2}{|c|}{$D x C u$} & $n s$ & $n s$ & $* * *$ & $* * *$ & $* * *$ & $* * *$ & $* * *$ & $* * *$ \\
\hline
\end{tabular}

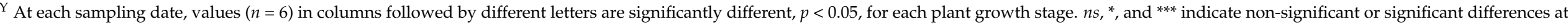
$p<5 \%$, and $0.1 \%$, respectively, following two-way ANOVA.

Table 4. Tolerance indices (TI (\%)) for Cu after 35 and 49 DAT in pelargonium plants grown hydroponically in perlite.

\begin{tabular}{|c|c|c|c|c|c|c|c|c|c|c|c|c|}
\hline \multirow{2}{*}{ DAT } & \multirow{2}{*}{$\begin{array}{l}\mathrm{Cu}^{2+} \\
(\mu \mathrm{M})\end{array}$} & \multicolumn{11}{|c|}{ Tolerance Indices-TI (\%) } \\
\hline & & Total Biomass & Plant height & Leaf No & Leaf FW & Stem FW & Petiole FW & Root FW & Leaf DW & Stem DW & Petiole DW & Root DW \\
\hline \multirow{4}{*}{35 days } & 4 & $100.00 \pm 0.00 \mathrm{ab}^{\mathrm{Y}}$ & $100.00 \pm 0.00$ & $100.00 \pm 0.00 \mathrm{a}$ & $100.00 \pm 0.00 \mathrm{ab}$ & $100.00 \pm 0.00 \mathrm{ab}$ & $100.00 \pm 0.00 \mathrm{~b}$ & $100.00 \pm 0.00$ & $100.00 \pm 0.00 \mathrm{ab}$ & $100.00 \pm 0.00$ & $100.00 \pm 0.00 \mathrm{~b}$ & $100.00 \pm 0.00$ \\
\hline & 25 & $111.30 \pm 1.93 \mathrm{a}$ & $102.70 \pm 3.98$ & $75.89 \pm 3.61 \mathrm{~b}$ & $114.85 \pm 0.12 \mathrm{a}$ & $117.05 \pm 11.33 \mathrm{a}$ & $139.71 \pm 4.48 \mathrm{a}$ & $113.49 \pm 4.23$ & $108.33 \pm 1.82 \mathrm{a}$ & $110.93 \pm 10.65$ & $127.97 \pm 1.03 \mathrm{a}$ & $98.97 \pm 6.01$ \\
\hline & 50 & $113.84 \pm 7.53 \mathrm{a}$ & $98.07 \pm 6.20$ & $78.46 \pm 10.85 b$ & $117.98 \pm 8.13 \mathrm{a}$ & $120.51 \pm 9.77 \mathrm{a}$ & $138.56 \pm 6.94 \mathrm{a}$ & $93.54 \pm 9.51$ & $111.93 \pm 8.57 \mathrm{a}$ & $109.79 \pm 7.88$ & $134.52 \pm 2.06 \mathrm{a}$ & $117.89 \pm 10.14$ \\
\hline & 100 & $88.31 \pm 8.01 \mathrm{~b}$ & $99.22 \pm 4.98$ & $68.71 \pm 8.76 \mathrm{~b}$ & $88.34 \pm 10.83 b$ & $81.90 \pm 8.49 \mathrm{~b}$ & $100.82 \pm 23.47 b$ & $91.53 \pm 15.81$ & $84.16 \pm 10.72 \mathrm{~b}$ & $87.92 \pm 3.94$ & $111.31 \pm 7.21 \mathrm{~b}$ & $93.33 \pm 12.07$ \\
\hline \multirow{4}{*}{49 days } & 4 & $100.00 \pm 0.00 \mathrm{~b}$ & $100.00 \pm 0.00$ & $100.00 \pm 0.00$ & $100.00 \pm 0.00$ & $100.00 \pm 0.00$ & $100.00 \pm 0.00$ & $100.00 \pm 0.00$ & $100.00 \pm 0.00$ & $100.00 \pm 0.00$ & $100.00 \pm 0.00$ & $100.00 \pm 0.00 \mathrm{~b}$ \\
\hline & 25 & $219.37 \pm 77.36 \mathrm{a}$ & $94.33 \pm 9.80$ & $72.12 \pm 11.84$ & $92.36 \pm 14.09$ & $100.74 \pm 12.76$ & $91.83 \pm 12.71$ & $94.11 \pm 3.02$ & $89.62 \pm 14.77$ & $103.03 \pm 13.16$ & $91.55 \pm 14.43$ & $92.56 \pm 1.19 \mathrm{~b}$ \\
\hline & 50 & $104.63 \pm 6.51 \mathrm{~b}$ & $103.45 \pm 17.39$ & $72.98 \pm 14.42$ & $96.47 \pm 5.56$ & $102.19 \pm 8.24$ & $92.66 \pm 6.20$ & $86.56 \pm 10.47$ & $98.95 \pm 5.91$ & $115.32 \pm 7.77$ & $101.20 \pm 5.87$ & $106.55 \pm 13.72 \mathrm{ab}$ \\
\hline & 100 & $89.36 \pm 15.10 b$ & $106.41 \pm 4.20$ & $91.03 \pm 8.03$ & $85.44 \pm 14.69$ & $83.03 \pm 12.44$ & $79.57 \pm 10.38$ & $98.23 \pm 1.84$ & $87.38 \pm 15.64$ & $93.41 \pm 15.21$ & $87.41 \pm 12.84$ & $124.10 \pm 1.03 \mathrm{a}$ \\
\hline
\end{tabular}

Significance

Days (D)

Copper $(\mathrm{Cu}$

nes

ns

ns $\quad n s$

ns $\quad$ ns

$\begin{array}{cc}n s & * * \\ * & *\end{array}$

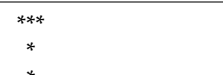

${ }^{\mathrm{Y}}$ At each sampling date, values $(n=6)$ in columns followed by $p<5 \%$, and $0.1 \%$, respectively, following two-way ANOVA. 


\subsection{Regression Analysis}

Pearson's correlation coefficients were determined between individual pairs of parameters associated with $\mathrm{Cu}$ uptake (leaf and root $\mathrm{Cu}$ concentrations), leaf antioxidant systems (content of total phenols and flavonoids, antioxidant capacity according to FRAP, DPPH and ABTS assays), and oxidative stress $\left(\mathrm{H}_{2} \mathrm{O}_{2}\right.$ and MDA) (Table 5).

Leaf $\mathrm{Cu}$ concentration was positively correlated to the root content of the element at both sampling dates. The correlation coefficients between leaf or root $\mathrm{Cu}$ and the biochemical parameters were generally higher at 49 than 35 DAT, and in older plants all correlations were positive except those involving MDA content.
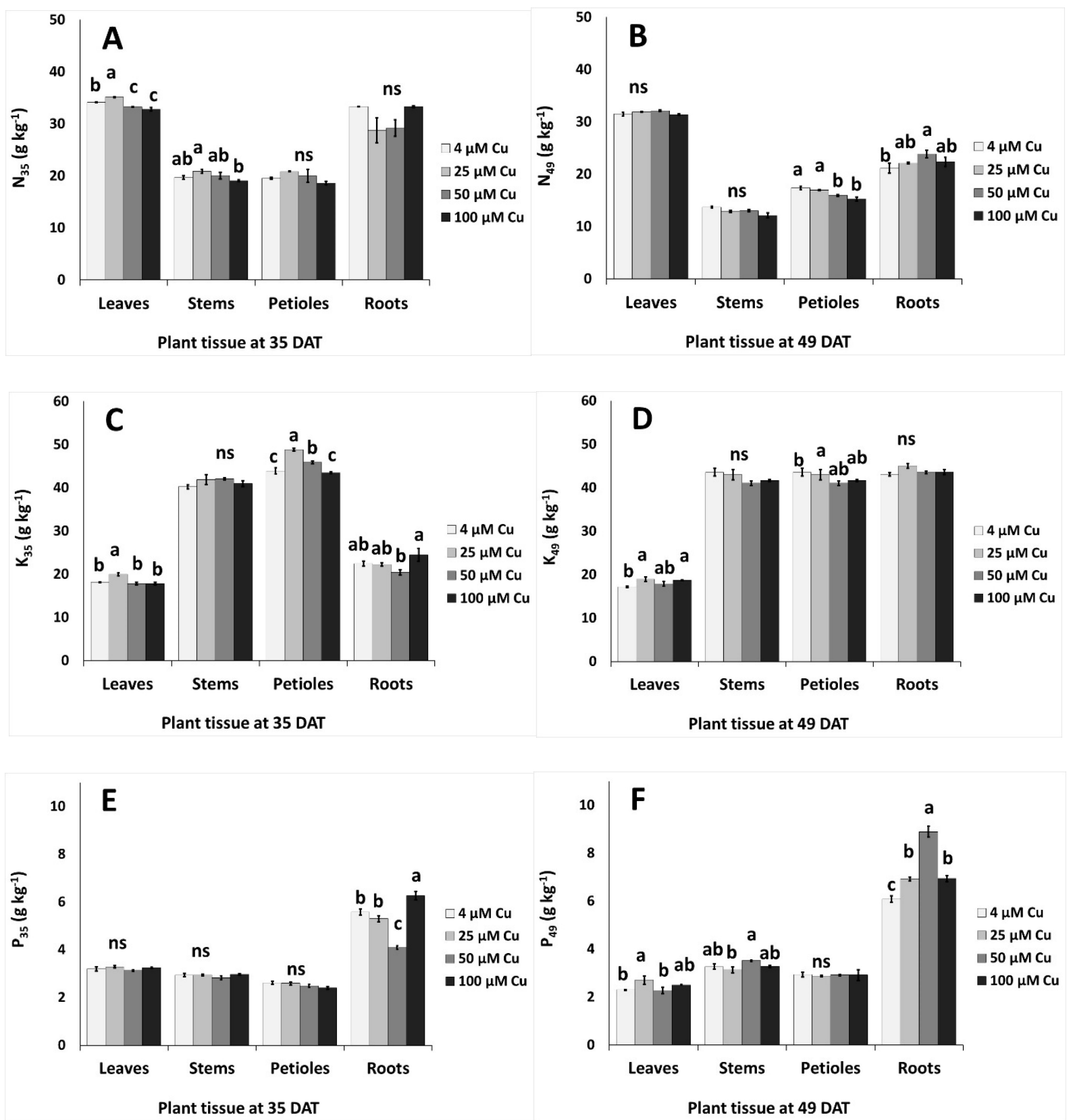

Figure 4. Cont. 

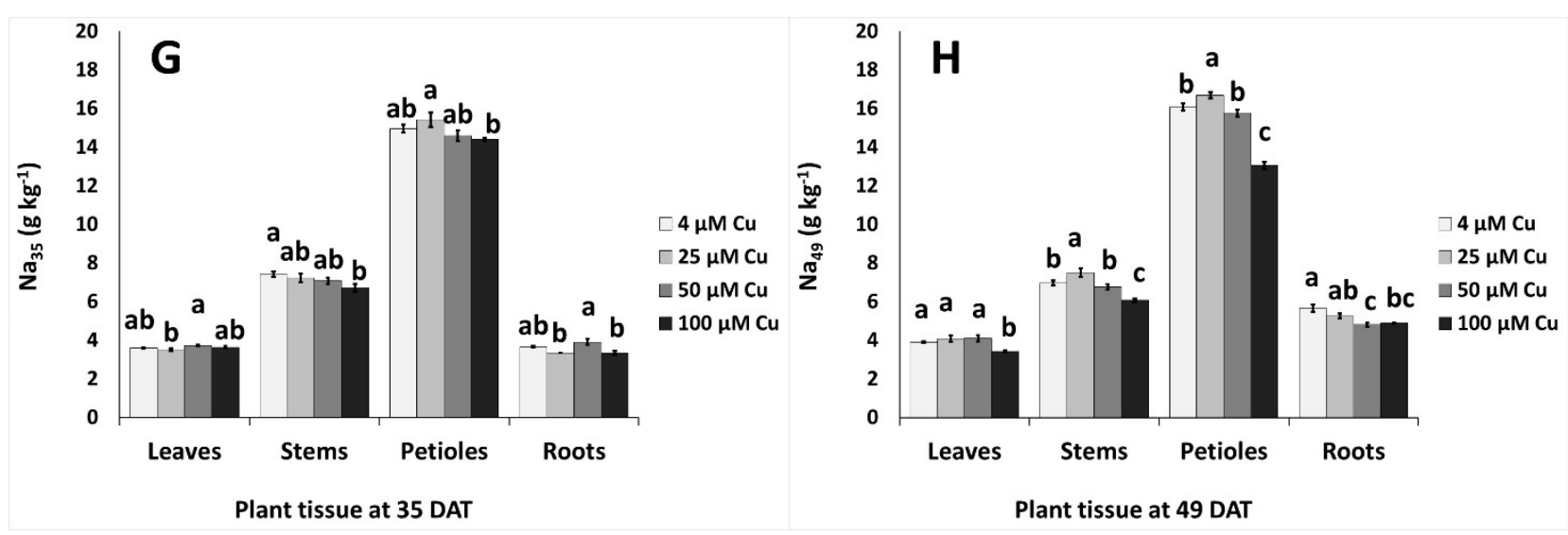

Figure 4. Effect of increasing copper $(\mathrm{Cu})$ concentration $\left(4-25-50-100 \mu \mathrm{M} \mathrm{Cu}^{2+}\right)$ in the nutriment solution and sampling date after transplanting (DAT, 35 days and 49 days) on the content of macronutrients and sodium in different organs of pelargonium plants grown hydroponically in perlite. (A,B) Nitrogen-N, (C,D) potassium-K, (E,F) phosphorus-P, $(\mathbf{G}, \mathbf{H})$ sodium-Na. Significant differences $(p<0.05)$ among $\mathrm{Cu}$ concentrations at each sampling date are indicated by different letters; ns indicates non-significant. Error bars show SE $(n=4)$.
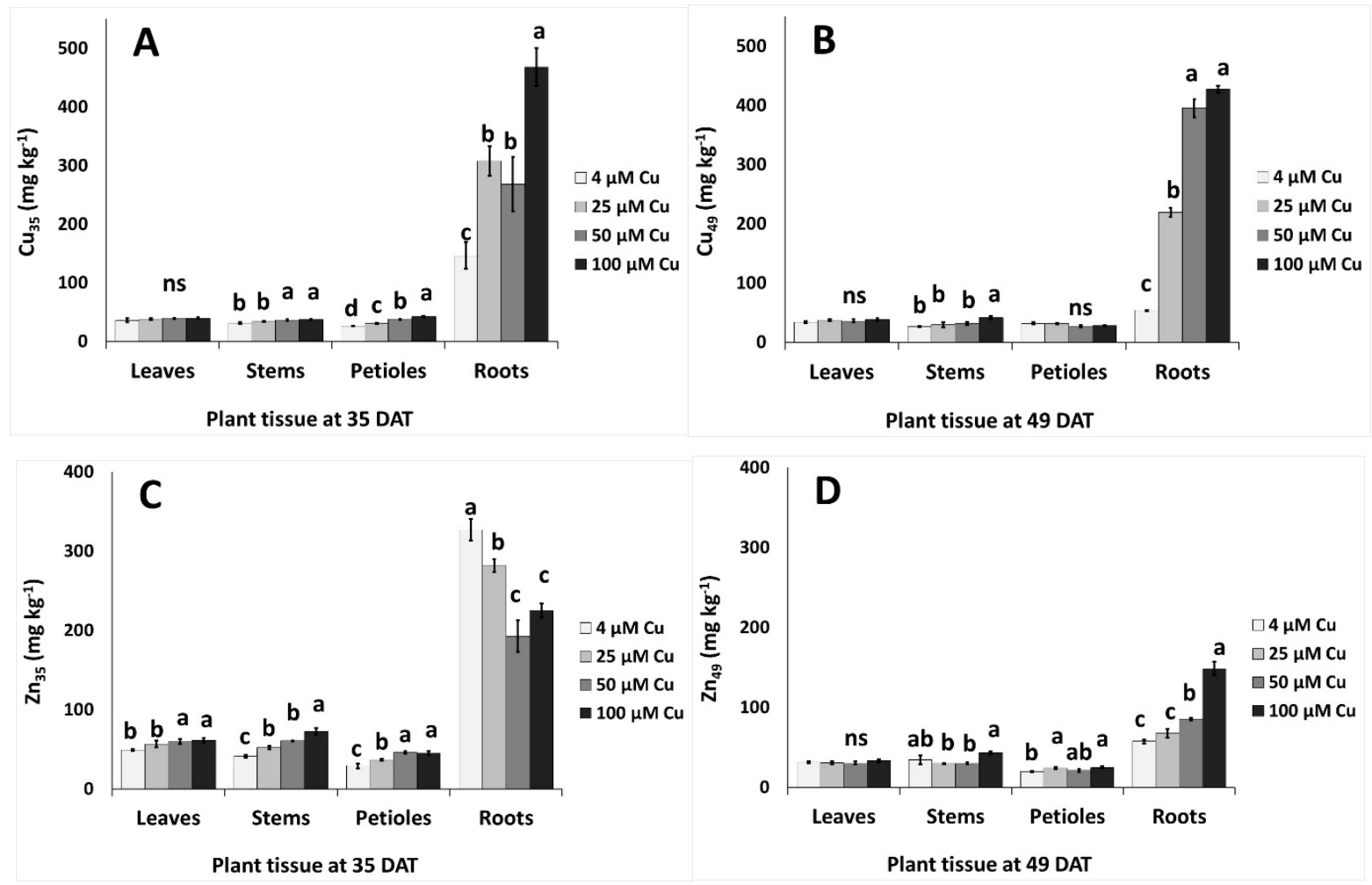

Figure 5. Effect of increasing copper $(\mathrm{Cu})$ concentration $\left(4-25-50-100 \mu \mathrm{M} \mathrm{Cu}^{2+}\right)$ in the nutriment solution and sampling date after transplanting (DAT, 35 days and 49 days) on the content of micronutrients in different organs of pelargonium plants grown hydroponically in perlite. (A,B) Copper-Cu, and (C,D) zinc-Zn. Significant differences $(p<0.05)$ among Cu concentrations at each sampling date are indicated by different letters; ns indicates non-significant. Error bars show SE $(n=4)$. 
Table 5. Pearson's correlation table for leaf and root content of copper $(\mathrm{Cu})$, leaf content of total phenols, flavonoids, $\mathrm{H}_{2} \mathrm{O}_{2}$ and malondialdehyde (MDA), and leaf antioxidant capacity determined using FRAP, DPPH or ABTS assays, in pelargonium plants grown hydroponically in perlite and exposed to four different $\mathrm{Cu}$ concentrations $\left(4-25-50-100 \mu \mathrm{M} \mathrm{Cu}{ }^{2+}\right)$ in the nutrient solution, sampled at 35 and 49 days after transplanting (DAT).

\begin{tabular}{|c|c|c|c|c|c|c|c|c|c|}
\hline & Leaf $\mathrm{Cu}$ & $\operatorname{Root} \mathrm{Cu}$ & Phenols & Flavonoids & $F R A P$ & DPPH & ABTS & $\mathrm{H}_{2} \mathrm{O}_{2}$ & MDA \\
\hline \multicolumn{10}{|l|}{35 DAT } \\
\hline Leaf Cu & 1 & & & & & & & & \\
\hline Root $\mathrm{Cu}$ & 0.8406 & 1 & & & & & & & \\
\hline Phenols & -0.3210 & -0.0500 & 1 & & & & & & \\
\hline Flavonoids & 0.4770 & -0.0714 & -0.4142 & 1 & & & & & \\
\hline FRAP & 0.4453 & -0.0852 & -0.2426 & 0.9835 & 1 & & & & \\
\hline DPPH & 0.5612 & 0.0339 & -0.3562 & 0.9920 & 0.9866 & 1 & & & \\
\hline ABTS & 0.5018 & 0.0037 & -0.1406 & 0.9551 & 0.9901 & 0.9750 & 1 & & \\
\hline $\mathrm{H}_{2} \mathrm{O}_{2}$ & -0.3121 & -0.0544 & 0.9996 & -0.3893 & -0.2161 & -0.3310 & -0.1139 & 1 & \\
\hline MDA & 0.5334 & 0.1429 & -0.9396 & 0.6778 & 0.5357 & 0.6432 & 0.4571 & -0.9308 & 1 \\
\hline \multicolumn{10}{|l|}{49 DAT } \\
\hline Leaf $\mathrm{Cu}$ & 1 & & & & & & & & \\
\hline Root $\mathrm{Cu}$ & 0.7078 & 1 & & & & & & & \\
\hline Phenols & 0.8042 & 0.8743 & 1 & & & & & & \\
\hline Flavonoids & 0.7933 & 0.9364 & 0.9890 & 1 & & & & & \\
\hline FRAP & 0.4427 & 0.9454 & 0.7185 & 0.8086 & 1 & & & & \\
\hline $\mathrm{DPPH}$ & 0.8973 & 0.3775 & 0.4626 & 0.4440 & 0.0855 & 1 & & & \\
\hline ABTS & 0.7591 & 0.8380 & 0.9954 & 0.9751 & 0.6881 & 0.4034 & 1 & & \\
\hline $\mathrm{H}_{2} \mathrm{O}_{2}$ & 0.4695 & 0.3948 & 0.7745 & 0.6815 & 0.2355 & 0.1705 & 0.8267 & 1 & \\
\hline MDA & -0.1303 & -0.6349 & -0.1807 & -0.3241 & -0.7818 & 0.0074 & -0.1173 & 0.4215 & 1 \\
\hline
\end{tabular}

\section{Discussion}

Plant growth and development are regulated by plant physiology, which in turn is tightly linked to both environmental conditions and, in hydroponic cultivation, to the composition of the nutrient solution that is supplied to the plants $[45,46]$. For evaluation of the effects of $\mathrm{Cu}$ toxicity, the choice of appropriate $\mathrm{Cu}$ levels depends on the species being tested, the duration of the $\mathrm{Cu}$ treatment, and other growing parameters such as the $\mathrm{pH}$ of the nutrient solution. In this study, hydroponically grown plants of $P$. graveolens were exposed to $\mathrm{Cu}$ concentrations of up to $100 \mu \mathrm{M}$. Similar concentrations were tested in several species including Moso bamboo [5], maize [15], or Carthamus tinctorius L. [1]. Although higher $\mathrm{Cu}$ levels have been reported for turfgrass $(120 \mu \mathrm{M})$ [16], and particularly for tomato (250 or $350 \mu \mathrm{M}$ ) [47,48], lower concentrations (up to $40 \mu \mathrm{M}$ ) were employed for both tree species [49] or vegetable crops [46].

In our experiments, all growth parameters were, of course, significantly higher at 49 than 35 DAT, with the only exceptions being plant height and total upper dry matter percentage, which were not affected by plant age. At 35 DAT, despite the lower number of leaves in Cu-treated plants than in the control, $\mathrm{Cu}$ concentrations up to $50 \mu \mathrm{M}$ in the nutrient solution increased the fresh biomass production of the aerial part (Table 1); however, a relevant increase in dry matter was observed only for stem tissues, suggesting that the overall effect was partially due to increased water absorption. In contrast, at 49 DAT the fresh weight of the distinct aboveground plant organs did not change across treatments (Figure 1), while the increase in dry mass percentage above $50 \mu \mathrm{M} \mathrm{Cu}$ (Table 1) indicated a lower water content in those tissues. An increase in the percentage of dry matter was observed also in the leaf tissues of tomato plants grown in hydroponics, after 15 days exposure to 100-350 $\mu \mathrm{M} \mathrm{Cu}$ concentrations [48]. The detrimental effect of high $\mathrm{Cu}$ levels in the root zone on biomass production was observed in several food crops [4], and in MAPs such as Carthamus tinctorius [1]. Similarly, in this work both fresh (Table 1) and dry (Figure 1) biomass production were tendentially lower in the $100 \mu \mathrm{M}$ Cu treatment than the control at both sampling dates, although the difference was never significant. These results showed that $P$. graveolens is a species tolerant to $\mathrm{Cu}$ toxicity of up to $100 \mu \mathrm{M}$ 
concentration, consistent with the tolerance indices toward metal stress reported in Table 4 . For each plant organ, the values of the latter parameters were generally similar to those of the corresponding control. Toxic $\mathrm{Cu}$ concentrations well below $100 \mu \mathrm{M}$ have been reported in the literature for several species. For example, Reichman et al. [50] reported that the highest $\mathrm{Cu}$ concentration in the nutrient solution without negative effects on plant growth was $35 \mu \mathrm{M}$ for $\mathrm{Cu}$-tolerant populations of Silene cucubalus; the no-effect threshold was about $5 \mu \mathrm{M}$ for $\mathrm{Cu}$-sensitive cultivars of mung bean, sweet potato and wheat, and was below $1 \mu \mathrm{M}$ in Australian tree species such as ironbark, Acacia holosericea, and Melaleuca leucadendra.

Plant age significantly influenced both stomatal resistance, which was much higher at 49 than 35 DAT for all the $\mathrm{Cu}$ treatments, and photosynthetic efficiency, expressed as chlorophyll fluorescence Fv/Fm, which was lower in older plants. At both sampling dates, increasing $\mathrm{Cu}$ concentrations in the nutrient solution interfered with the process of photosynthesis by increasing stomatal resistance and decreasing leaf chlorophyll fluorescence (Table 2). Along with the determination of stomatal resistance, the assessment of chlorophyll fluorescence is a key parameter in the rapid detection of response to physiological stress in higher plants; specifically, the Fv/Fm ratio is a physiological marker of photoinhibition of photosystem II (PSII) induced by stress conditions [51]. It has been reported that excess $\mathrm{Cu}$ can impair photosynthetic electron transport particularly at the PSII level, and $\mathrm{Cu}$ toxicity has been associated with quenching of variable fluorescence $\mathrm{Fv}$ [52]. The values of Fv/Fm reported in Table 2 remained within the typical range for healthy plants, that is $0.75-0.85$ [53], and suggested that, despite a significant decline of the indicator at the $100 \mu \mathrm{M} \mathrm{Cu}$ concentration at both sampling dates, the function of the PSII reaction centers was preserved with all $\mathrm{Cu}$ treatments. Although plant age did not affect the content of chlorophylls, a significant decrease with increasing $\mathrm{Cu}$ concentration was observed at 49 DAT for these pigments. The above data could be reasonably interpreted as early indicators of $\mathrm{Cu}$ toxicity that became more severe with the duration of exposure; despite the effects of a possible photosynthetic imbalance this did not translate into a significant biomass decrease, or in the typical visible symptoms of toxicity such as leaf chlorosis [54]. Under impaired photosynthesis, plant metabolism is affected and one possible biochemical process that can be activated is the Mehler reaction, with formation of oxygenated molecules such as $\mathrm{H}_{2} \mathrm{O}_{2}$ [55]. This process is consistent with the significant increase in $\mathrm{H}_{2} \mathrm{O}_{2}$ concentration that was observed at 49 DAT in plants treated with $100 \mu \mathrm{M}$ $\mathrm{Cu}$ (Figure 3A).

It is generally acknowledged that excess $\mathrm{Cu}$ causes oxidative stress in plants $[1,2,13,17]$. However, due to the time course of the antioxidant response, the levels of stress indicators in plant tissues may undergo fluctuations. This could account for the significant effect of sampling date, $\mathrm{Cu}$ concentration, and their interaction on the observed contents of both $\mathrm{H}_{2} \mathrm{O}_{2}$ and $\mathrm{MDA}$, and could also explain the contrasting results reported in the literature concerning the levels of ROS or MDA in several plant species [4]. The antioxidant activity of pelargonium at 35 DAT showed the same behavior across the $\mathrm{Cu}$ treatments (Figure 2C-E), regardless of the assay used for the determination (FRAP, DPPH or ABTS) and the stimulation of the plant antioxidant response was strictly related to the occurrence of lipid peroxidation, since a similar pattern was observed also for the concentration of MDA (Figure 3B). The content of total flavonoids followed the same trend (Figure 2B), suggesting that this class of compounds could play a key role in the pool of antioxidant molecules of $P$. graveolens that are involved in plant response to excess $\mathrm{Cu}$ in the early stages of exposure. Interestingly, the highest values of antioxidant power and flavonoid concentration were obtained with the $50 \mu \mathrm{M} \mathrm{Cu}$ treatment, which also resulted in the highest rate of $\mathrm{Cu}$ accumulation in plant tissues (Table 3). On the other hand, a different behavior was observed for total phenols (Figure 2A), whose amount, unlike the content of flavonoids, was affected also by the sampling date. These dissimilarities indicated that, along with flavonoids, other classes of phenolic compounds could contribute significantly to the pool of phenolics of this species. 
At 49 DAT, all parameters except DPPH scavenging capacity increased with $\mathrm{Cu}$ concentration (Figure 2), suggesting the occurrence of an effective dose-dependent response of the antioxidant system to excess $\mathrm{Cu}$ and a central role of phenolic compounds in the plant tolerance to $\mathrm{Cu}$ toxicity. These findings showed the effectiveness of high $\mathrm{Cu}$ concentrations in the nutrient solution in stimulating the synthesis and accumulation of beneficial antioxidant molecules in the plant tissues of P. graveolens. In addition to phenolics, other non-enzymatic antioxidant compounds could have an impact on plant response to $\mathrm{Cu}$ toxicity; for example, an increased content of proline has been observed in different species exposed to excess $\mathrm{Cu}[18,19]$. In our experiments, the level of MDA decreased with $\mathrm{Cu}$ concentration in the nutrient solution up to $50 \mu \mathrm{M}$, showing that $\mathrm{Cu}$-exposed P. graveolens could well counteract lipid peroxidation. Likewise, the leaf concentration of $\mathrm{H}_{2} \mathrm{O}_{2}$ was effectively controlled in up to $50 \mu \mathrm{M} \mathrm{Cu}$. In contrast, the increase in the content of $\mathrm{H}_{2} \mathrm{O}_{2}$ at $100 \mu \mathrm{M} \mathrm{Cu}$ may indicate a less efficient plant response at this high concentration of the element (Figure 3A,B).

The relationships among the indicators linked to $\mathrm{Cu}$ uptake and antioxidant response to $\mathrm{Cu}$ treatments are confirmed in the Pearson's correlation table (Table 5). Leaf Cu content followed root content at both sampling dates, and, in younger plants, the content of flavonoids rather than the level of total phenols was strongly correlated with the antioxidant capacity as obtained using either the FRAP, DPPH or ABTS assays. However, at 35 DAT, Cu exposure did not elicit a marked response, as extremely weak relationships were evidenced between $\mathrm{Cu}$ levels in the tissues and all other biochemical parameters. The correlation coefficients between the concentrations of $\mathrm{Cu}$ and those of $\mathrm{H}_{2} \mathrm{O}_{2}$ and MDA also remained low at $49 \mathrm{DAT}$, suggesting that even older plants could efficiently prevent oxidative stress. On the other hand, higher values of the correlation coefficients were generally evidenced between root or leaf $\mathrm{Cu}$ levels and the other biochemical parameters (phenols or flavonoids content, or antioxidant capacity). Therefore, the results of the regression analysis are consistent with an initial antioxidant response to $\mathrm{Cu}$ toxicity at 49 DAT.

The TF and BAC indexes are important parameters for the evaluation of plant phytoremediation potential. In hyperaccumulator species, both parameters are greater than 1 ; in contrast, in our study only the BAC factor was higher than 1 , indicating that $P$. graveolens acted as a $\mathrm{Cu}$ excluder. According to Saleem et al. [13]. Cu excluders, which have a low potential for metal extraction, could be effectively employed for phytostabilization. The BAC and TF indexes showed significant decreases with increasing Cu concentration in the nutrient solution at both sampling dates (Table 3). At low concentrations (up to $25 \mu \mathrm{M}$ ), young plants accumulated more $\mathrm{Cu}$ in root tissues and showed a much larger variation of the root BAC index among the $\mathrm{Cu}$ treatments than those sampled at 49 DAT. However, the decrease of root BAC values at both sampling dates indicated a strong inhibition of $\mathrm{Cu}$ uptake as the concentration of the element in the nutrient solution increased. A much larger variation was observed for the BAC index of the aerial parts, which decreased more than 10-fold in all aboveground tissues during the whole growing cycle, suggesting a synergistic effect of reduced $\mathrm{Cu}$ uptake and reduced element translocation in $\mathrm{Cu}$-treated plants. This outcome was confirmed by lower TF values in the $\mathrm{Cu}$ treatments as compared to the control. Although in the latter treatment the TF in the aboveground tissues was higher in older plants, $\mathrm{Cu}$ translocation was markedly limited with increasing $\mathrm{Cu}$ concentration at both sampling dates. Therefore, the observed tolerance of $P$. graveolens to $\mathrm{Cu}$ toxicity was both due to the plant's ability to exclude $\mathrm{Cu}$ from the leaf tissues by limiting translocation to the aerial parts, and to an efficient antioxidant system. A similar behavior was observed in Solanum cheesmaniae subjected to $\mathrm{Cu}$ stress [56]. This effect was further evidenced by the results shown in Figure 5A,B, as $\mathrm{Cu}$ accumulated particularly in root tissues independent of the concentration of the nutrient solution. In contrast, the stems were only slightly affected by the $100 \mu \mathrm{M} \mathrm{Cu}$ treatment, and the leaf tissues were totally unaffected.

According to Lange et al. [57], most $\mathrm{Cu}$-tolerant species act as $\mathrm{Cu}$ excluders, with very low $\mathrm{Cu}$ translocation from root to shoots. Contrarily, Chen et al. [5] reported on 25 plant 
species identified as $\mathrm{Cu}$ hyperaccumulators and provided literature data concerning tolerant and accumulator species, with leaf $\mathrm{Cu}$ content ranging from 45 to $596 \mathrm{mg} / \mathrm{kg}$ DW and root content ranging from 33 to $3768 \mathrm{mg} \mathrm{kg}^{-1} \mathrm{DW}$. In plants, $\mathrm{Cu}$ uptake is generally dependent on the species, plant organ, concentration in the growing medium, and the time of exposure. For example, according to Adrees et al. [4], maize plants exposed for six days to $100 \mu \mathrm{M} \mathrm{Cu}$ in hydroponics accumulated 1070 and $56 \mathrm{mg} \mathrm{kg}^{-1} \mathrm{DW}$ in roots and shoots, respectively; the same species was reported to accumulate $7790 \mathrm{mg} \mathrm{kg}^{-1} \mathrm{DW}$ in the roots after 15 days treatment with $80 \mu \mathrm{M} \mathrm{Cu}$. Chen et al. [5] reported that in hydroponically grown Moso bamboo with $100 \mu \mathrm{M} \mathrm{Cu}$ in the nutrient solution, the $\mathrm{Cu}$ content in leaf and root tissues were, respectively, 24 and $417 \mathrm{mg} \mathrm{kg}^{-1} \mathrm{DW}$ after 15 days, and 91 and $809 \mathrm{mg} \mathrm{kg}^{-1}$ DW after 30 days exposure. Saleem et al. [13] reported that pot-grown flax accumulated $\mathrm{Cu}$ mainly in the root tissues after 35 days cultivation, while the contaminant was accumulated mainly in the shoots in mature plants (105-140 days). In our experiments, despite a dose-dependent $\mathrm{Cu}$ accumulation in the roots of up to $468.14 \mathrm{mg} \mathrm{kg}^{-1} \mathrm{DW}, \mathrm{Cu}$ content in the leaf tissues remained at the same level as the control both at 35 and 49 DAT, further characterizing $P$. graveolens as a $\mathrm{Cu}$ excluder species.

In a very recent paper, Tschinkel et al. [58] reported that the permitted concentration of impurities for drug substances and excipients set by the United States Pharmacopoeia Convention (USP) is $300 \mathrm{mg} \mathrm{kg}^{-1}$. Additionally, according to a recent review from the European Food Safety Authority [59], the maximum residue level (MRL) for Cu compounds $(\mathrm{Cu})$ in leaves and herbs for herbal infusions is $100 \mathrm{mg} \mathrm{kg}^{-1}$. These limits are much higher than the $\mathrm{Cu}$ concentrations that were found in the leaf tissues of $P$. graveolens, which were below $50 \mathrm{mg} \mathrm{kg}^{-1}$ DW (Figure 5A,B). Therefore, the leaves of Cu-treated P. graveolens plants had higher contents of antioxidants and, at the same time, the same $\mathrm{Cu}$ content of the control plants, and may be safely used in the pharmaceutical/herbal industry for the extraction of phenolic compounds and other beneficial constituents such as essential oils. Although the latter were not examined in this work, some authors showed that heavy metals had minimal impact on the quality of $P$. graveolens essential oil, even when the contaminant was partly translocated to the aboveground organs $[38,39]$. In general, despite a high translocation factor from the root system to the aerial parts being indispensable for species with edible roots, the opposite is preferable for plant species that are used for leaf tissues, like the one examined in this study. Considering the excess of $\mathrm{Cu}$ application in agriculture and the consequent contamination of soils and water bodies, selection of MAPs according to their tolerance and potential accumulation in the organs of interest becomes a crucial issue in managing the problem of $\mathrm{Cu}$ pollution and preserving the quality of plant materials. It is noteworthy to mention that expanded and unexpanded perlite have some properties that can favor the adsorption of metal ions, including $\mathrm{Cu}$ [60]. However, the strong root $\mathrm{Cu}$ uptake shown in Figure 5A,B showed that this microelement was available to the plants in all $\mathrm{Cu}$ treatments.

Copper had a strong influence on Zn uptake (Figure 5C,D). In the root tissues of younger plants, $\mathrm{Zn}$ content was inversely related to that of $\mathrm{Cu}$; this indicated a competitive absorption mechanism for the two micronutrients, in agreement with what reported by Kabata-Pendias and Szteke [7]. The amount of Zn in the aerial parts at 35 DAT increased significantly across the $\mathrm{Cu}$ treatments, suggesting that higher $\mathrm{Cu}$ levels promoted $\mathrm{Zn}$ translocation to the stems. Conversely, $\mathrm{Cu}$ and $\mathrm{Zn}$ uptake followed the same trend in older plants, despite a much lower Zn accumulation at 49 than 35 DAT. A decrease of Zn uptake in plants exposed to excess $\mathrm{Cu}$ has been observed in several species [4]. The content of $\mathrm{Na}$ decreased with increasing $\mathrm{Cu}$ in all plant organs, especially at $49 \mathrm{DAT}$, in agreement with what reported by Chrysargyris et al. [49] for the roots of Mentha spicata. The opposite trend was observed by other authors in the leaves of Vicia faba [61] and the shoots of pistachio seedlings [62]. The addition of $\mathrm{Cu}$ to the nutrient solution generally did not have a significant influence on the uptake of the macronutrients $\mathrm{N}, \mathrm{P}$ and $\mathrm{K}$, which was confirmed the scarce effects observed on the biomass production (Table 1 and Figure 1). The only exception was root $\mathrm{P}$ content at $49 \mathrm{DAT}$, which was higher in $\mathrm{Cu}$-treated plants than in 
controls (Figure 4E,F), in contrast with the results reported by Chrysargyris et al. [49] and Eskandari and Mozaffari [62]. According to Adrees et al. [4], although Cu supply generally affects mineral nutrition, the effect of this microelement on the uptake of other mineral nutrients is strongly dose-, time- and species-dependent. In addition, in polluted environments, $\mathrm{Cu}$ could interact with other heavy metal contaminants $[9,26,51,63]$. In general, we observed that the $\mathrm{Cu}$ treatments did not impair mineral nutrition and, overall, P. graveolens showed a high capacity to grow in Cu-enriched mediums of up to $100 \mu \mathrm{M}$.

Further work is necessary to provide a deeper insight into the response of P. graveolens to $\mathrm{Cu}$ stress. For example, the effects of severe $\mathrm{Cu}$ exposure conditions could be investigated through an extension of the growing period beyond 49 DAT, or with $\mathrm{Cu}$ concentrations higher than $100 \mu \mathrm{M}$ in the nutrient solution; additionally, a similar experiment could be carried out in open field, where $\mathrm{Cu}$ bioavailability is conditioned by soil properties; finally, the profiling of individual metabolites of interest under $\mathrm{Cu}$ stress could help in highlighting the effects of this element on the bioactive properties of P. graveolens.

\section{Materials and Methods}

\subsection{Plant Material and Cultivation Conditions}

Pelargonium graveolens L'Hér. plants were selected for the present study, which was implemented at the experimental greenhouse of Cyprus University of Technology, in Limassol, Cyprus. Cuttings of $10 \mathrm{~cm}$ length were collected from mother plants (National Agricultural Department, Nicosia, Cyprus) and were grown in peat:perlite $(4: 1 v / v)$ substrate, in plastic seedling trays for 25 days, till roots formation. Plants at the stage of four-to-five leaves were transplanted in pots (one plant per pot; $1.5 \mathrm{~L}$ capacity) filled with expanded perlite and placed on plastic trays to achieve proper drainage (see Chrysargyris et al. [64]). Perlite properties have been described previously [65]. Plants were grown in an open (free drainage) hydroponic system and the drainage nutrient solution was available to plants through capillary suction. Plants were sampled at two different growth stages.

Plants were initially grown with the application of a full-strength nutrient solution (electrical conductivity (EC) and $\mathrm{pH}$ of $2.1 \mathrm{mS} \mathrm{cm}^{-1}$ and 5.7, respectively) for 21 days. Nutrient solution composition was: $\mathrm{NO}_{3}{ }^{-}-\mathrm{N}=15.00, \mathrm{~K}=9.50, \mathrm{PO}_{4}{ }^{-3}-\mathrm{P}=1.80, \mathrm{Ca}=4.20$, $\mathrm{Mg}=1.63, \mathrm{SO}_{4}{ }^{-2}-\mathrm{S}=1.55$ and $\mathrm{Na}=1.85 \mathrm{mmol} \mathrm{L}^{-1}$, respectively; and $\mathrm{B}=30.00, \mathrm{Fe}=35.05$, $\mathrm{Mn}=6.10, \mathrm{Cu}=4.00, \mathrm{Zn}=4.10$, and $\mathrm{Mo}=0.52 \mu \mathrm{mol} \mathrm{L}^{-1}$, respectively. The described above concentrations were obtained using mineral salts and chelate for iron with ethylenediamineN-N'bis(2-hydroxy-4-methylphenylacetic) acid (6.5\% Fe EDDHMA). After that period, plants were subjected to different $\mathrm{Cu}$ levels (treatments) in the nutrient solution, namely (i) $4 \mu \mathrm{M} \mathrm{Cu}$ (control); (ii) $25 \mu \mathrm{M} \mathrm{Cu}$; (iii) $50 \mu \mathrm{M} \mathrm{Cu}$; and (iv) $100 \mu \mathrm{M} \mathrm{Cu}$ (in the form of $\mathrm{CuSO}_{4}$ ). Plants were grown under $\mathrm{Cu}$ excess for additional 28 days (in total 49 days after transplanting, DAT). A total of 96 plants were used $(4 \mathrm{Cu}$ levels $\times 2$ sampling periods $\times 12$ replicates).

\subsection{Plant Growth and Physiological Measurements}

Plant growth and physiological parameters were measured at two sampling periods (35 DAT and 49 DAT) with six replicates per treatment and growth period. Plant height and leaf number were recorded. After harvest, upper fresh and dry biomass parts (leaves, petioles, leaf stem) and roots were measured. Different parts of the plants were separated to evaluate the uptake and translocation of $\mathrm{Cu}$ from the roots to upper plant parts and the relevant effects on nutrient accumulation. Individual samples were collected and put at $85^{\circ} \mathrm{C}$ in a forced-air oven until constant weight was achieved to determine their dry weight.

Leaf stomatal conductance was measured with a $\Delta$ T-Porometer AP4 (Delta-T Devices Cambridge, Burwell, Cambridge, UK) [66]. Leaf chlorophyll fluorescence (chlorophyll fluorometer, opti-sciences OS-30p, Hertfordshire, UK) was measured on two fully developed, light-exposed leaves per plant. Following leaf incubation in the dark for 20 min, the Fv / Fm ratio was measured [66]. Leaf chlorophyll was extracted with dimethyl sulfoxide (DMSO) 
and chlorophyll a ( $\mathrm{Chl} \mathrm{a),} \mathrm{chlorophyll} \mathrm{b} \mathrm{(} \mathrm{Chl} \mathrm{b}$ ) and total chlorophylls (total $\mathrm{Chl}$ ) were assayed and expressed as $\mu \mathrm{g} \mathrm{g}^{-1} \mathrm{FW}$ [66].

\subsection{Antioxidant Activity, Total Phenols and Total Flavonoids Content}

The antioxidant activity of the methanolic leaf plant extracts was determined with four replicates per treatment and sampling date by the assays of 2,2-diphenyl-1-picrylhydrazyl (DPPH) and ferric reducing antioxidant power (FRAP), as previously described by Chrysargyris et al. [67], as well as the 2,2'-azino-bis(3-ethylbenzothiazoline-6-sulphonic acid) (ABTS) assay according to the methodology described by Woidjylo et al. [68]. The Folin-Ciocalteu method was used for determining the total phenols content, as previously described [69] and results were expressed as gallic acid equivalents (mg GAE per g FW). The total flavonoid content was determined according to aluminum chloride colorimetric method [70] and results were expressed as rutin equivalents (mg rutin per $\mathrm{g} F W$ ).

\subsection{Plant Stress Indicators}

Cell damage index of lipid peroxidation in leaves was assessed in terms of malondialdehyde (MDA) content, which was determined by the thiobarbituric acid reaction [71]. Hydrogen peroxide $\left(\mathrm{H}_{2} \mathrm{O}_{2}\right)$ content was measured according to the method of Loreto and Velikova [47]. The results were expressed as nmol MDA or $\mu \mathrm{mol} \mathrm{H}_{2} \mathrm{O}_{2}$ per g FW. Four replicates were analyzed for each treatment and sampling date.

\subsection{Nutrient Content}

Dried tissue $(0.5 \mathrm{~g})$ from leaves, stems, leaf petioles and roots from each treatment $(4 \mathrm{bi}-$ ological replications; each replication was a pool of 2 individual plants) at both sampling dates, was subjected to dry ashing at $450{ }^{\circ} \mathrm{C}$ and acid extraction $(2 \mathrm{~N} \mathrm{HCl})$. The extracts were used for the determination of sodium $(\mathrm{Na})$ and potassium $(\mathrm{K})$ by flame photometry (Lasany Model 1832, Lasany International, Panchkula, India), phosphorus (P) with the molybdate/vanadate method (yellow method) by spectrophotometry (Multiskan GO, Thermo Fischer Scientific, Waltham, MA, USA), zinc $(\mathrm{Zn})$ and copper $(\mathrm{Cu})$ by atomic absorption spectrometry (PG Instruments AA500FG, Leicestershire, UK). Nitrogen (N) was determined using the Kjeldahl method (BUCHI, Digest automat K-439 and Distillation Kjelflex K-360, Flawil, Switzerland) following Chrysargyris et al. [64]. In particular, the measured $\mathrm{Cu}$ content in this study refers to total dissolved $\mathrm{Cu}$ content, which was almost totally ( $\geq 98.21 \%$ ) available as $\mathrm{Cu}^{2+}$ [49]. Plant nutrient content was expressed in $\mathrm{g} \mathrm{kg}^{-1}$ and $\mathrm{mg} \mathrm{kg}^{-1} \mathrm{DW}$, for macronutrients and micronutrients, respectively.

The $\mathrm{Cu}$ accumulation rate (AR), bioaccumulation coefficient (BAC), translocation factor (TF) and tolerance index (TI) of pelargonium were calculated by equations described by Benimeli et al. [72], Amin et al. [2] and Azooz et al. [73], as follows.

The accumulation rate (AR) was calculated as the sum up of $\mathrm{Cu}$ concentration in each plant tissue $\mathrm{x}$ plant DW divided by the number of days under $\mathrm{Cu}$ levels by the total plant DW [72].

Accumulation rate $\mathrm{mg}$ per $(\mathrm{kg} \mathrm{DW} \mathrm{x}$ day $)=$

$\underline{([\mathrm{Cu}] \text { leave } \mathrm{x} \text { DW leave }+([\mathrm{Cu}] \text { stem } \times \mathrm{DW} \text { stem }+([\mathrm{Cu}] \text { petiole } \times \mathrm{DW} \text { petiole }+([\mathrm{Cu}] \text { root } \times \mathrm{DW} \text { root })}$

The bioaccumulation coefficient (BAC) was calculated as the ratio of $\mathrm{Cu}$ concentration in plant tissue to that of $\mathrm{Cu}$ concentration in nutrient solution, according to Amin et al. [2]:

$$
\text { Bioaccumulation coefficient }=\frac{\mathrm{Cu} \text { concentration in plant tissue }(\mathrm{mg} \mathrm{kg} \mathrm{DW})}{\mathrm{Cu} \text { concentration in nutrient solution }(\mathrm{mg} \text { per L) }}
$$

The translocation factor (TF) was calculated as the ratio of $\mathrm{Cu}$ concentration in plant tissue to that of $\mathrm{Cu}$ concentration in plant roots according to Amin et al. [2]:

$$
\text { Translocation factor }=\frac{\mathrm{Cu} \text { concentration in plant tissue }(\mathrm{mg} \mathrm{kg} \mathrm{DW})}{\mathrm{Cu} \text { concentration in plant root }(\mathrm{mg} \text { per } \mathrm{kg} \mathrm{DW})}
$$


Copper tolerance index (TI) was calculated as the quotient of the dry weight of plants grown under copper treated and control conditions according to the following the equations described by Benimeli et al. [72] and Azooz et al. [73], with the following modifications:

$$
\text { Tolerance index }(\%)=\frac{\text { Dry weight of } \mathrm{Cu}-\text { treated plants } \times 100}{\text { Dry weight of } \mathrm{Cu}-\text { untreated plants }(\text { control })}
$$

\subsection{Statistical Analysis}

For plant growth and physiological measurements, six samples were used per treatment, whereas chemical composition/antioxidants were recorded from four samples per treatment. The analysis of the data was accomplished with the use of SPSS v. 22.0 program (IBM Corp., Armonk, NY, USA) and the one-way analysis of variance (ANOVA) was carried out for the $\mathrm{Cu}$ concentration for each sampling date, while means were compared with the Duncan multiple range test (DMRT) at $p<0.05$, when significant differences were detected. Results were expressed as mean values and standard error (SE). The two-way ANOVA was also performed, with both $\mathrm{Cu}$ concentration and sampling date as the sources of variation. Finally, a regression analysis was applied to the content of $\mathrm{Cu}$ in plant tissues and the biochemical parameters associated with antioxidant response and oxidative stress.

\section{Conclusions}

Hydroponically grown $P$. graveolens resulted in a species tolerant toward high $\mathrm{Cu}$ concentrations in the root zone and the initial symptoms of $\mathrm{Cu}$ toxicity. Namely, declines of photosynthesis-related parameters and increases in leaf $\mathrm{H}_{2} \mathrm{O}_{2}$ along with considerable $\mathrm{Cu}$ accumulation in root tissues were evidenced only at the $100 \mu \mathrm{M} \mathrm{Cu}$ concentration in the nutrient solution. However, the extent of the toxicity symptoms did not have an impact on biomass production; in addition, high $\mathrm{Cu}$ levels stimulated plant secondary metabolism, enhancing the production of bioactive antioxidant molecules. Due to low $\mathrm{Cu}$ translocation to the aerial organs during the whole growing cycle, this microelement did not reach the leaf tissues, which resulted in suitable plant material for the safe extraction of bioactive compounds. These results show that plant stress from excess $\mathrm{Cu}$ does not necessarily preclude the use of MAPs for medicinal purposes, depending on the target organ where the metal accumulates. The outcome of this study showed that the leaves of $P$. graveolens plants exposed to excess $\mathrm{Cu}$ could be safely employed for their medicinal properties in herbal or pharmaceutical preparations.

Author Contributions: Conceptualization, A.C., R.M. and N.T.; methodology, A.C. and R.M.; software, A.C.; validation, A.C., R.M., L.I., and A.P.; formal analysis, A.C., R.M. and L.I.; investigation, A.C. and R.M.; resources, A.C. and N.T.; data curation, A.C., R.M., L.I., and A.P.; writing-original draft preparation, R.M. and N.T.; writing—review and editing, R.M., L.I., A.P. and N.T.; visualization, R.M. and L.I.; supervision, A.C. and N.T.; project administration, N.T.; funding acquisition, L.I., A.P. and N.T. All authors have read and agreed to the published version of the manuscript.

Funding: This research has been co-financed by Cyprus University of Technology and University of Pisa Open Access Author Fund.

Acknowledgments: Authors would like to thank Filio Athinodorou and Panayiota Xylia for their technical assistance.

Conflicts of Interest: The authors declare no conflict of interest.

\section{References}

1. Gautam, S.; Anjani, K.; Srivastava, N. In vitro evaluation of excess copper affecting seedlings and their biochemical characteristics in Carthamus tinctorius L. (variety PBNS-12). Physiol. Mol. Biol. Plants 2016, 22, 121-129. [CrossRef]

2. Amin, H.; Arain, B.A.; Jahangir, T.M.; Abbasi, A.R.; Mangi, J.; Abbasi, M.S.; Amin, F. Copper (Cu) tolerance and accumulation potential in four native plant species: A comparative study for effective phytoextraction technique. Geol. Ecol. Landsc. 2019, 5, 1-12. [CrossRef] 
3. MacKie, K.A.; Müller, T.; Kandeler, E. Remediation of copper in vineyards-A mini review. Environ. Pollut. 2012, 167, 16-26. [CrossRef]

4. Adrees, M.; Ali, S.; Rizwan, M.; Ibrahim, M.; Abbas, F.; Farid, M.; Zia-ur-Rehman, M.; Irshad, M.K.; Bharwana, S.A. The effect of excess copper on growth and physiology of important food crops: A review. Environ. Sci. Pollut. Res. 2015, $22,8148-8162$. [CrossRef]

5. Chen, J.; Shafi, M.; Li, S.; Wang, Y.; Wu, J.; Ye, Z.; Peng, D.; Yan, W.; Liu, D. Copper induced oxidative stresses, antioxidant responses and phytoremediation potential of Moso bamboo (Phyllostachys pubescens). Sci. Rep. 2015, 5, 13554. [CrossRef]

6. Council of the European Union. Directive 86/278/EEC of 12 June 1986 on the protection of the environment, and in particular of the soil, when sewage sludge is used in agriculture (2018). Official Journal of the European Union, 4 July 2018; L 181, consolidated version.

7. Kabata-Pendias, A.; Szteke, B. Copper: Trace Elements in Abiotic and Biotic Environments; CRC Press, Taylor \& Francis Group: Abingdon, UK, 2015; p. 468.

8. Conry, R.R. Copper: Inorganic and Coordination Chemistry. Encyclopedia of Inorganic and Bioinorganic Chemistry; John Wiley and Sons: Hoboken, NJ, USA, 2011.

9. Wintz, H.; Fox, T.; Vulpe, C. Responses of plants to iron, zinc and copper deficiencies. Biochem. Soc. Trans. 2002, 30, 766-768. [CrossRef]

10. Mahmood, T.; Islam, K.R. Response of rice seedlings to copper toxicity and acidity. J. Plant Nutr. 2006, 29, 943-957. [CrossRef]

11. Li, S.; Zhang, G.; Gao, W.; Zhao, X.; Deng, C.; Lu, L. Plant growth, development and change in GSH level in Safflower (Carthamus tinctorius L.) exposed to copper and lead. Arch. Biol. Sci. 2015, 67, 385-396. [CrossRef]

12. Rizwan, M.; Meunier, J.D.; Davidian, J.C.; Pokrovsky, O.S.; Bovet, N.; Keller, C. Silicon alleviates Cd stress of wheat seedlings (Triticum turgidum L. cv. Claudio) grown in hydroponics. Environ. Sci. Pollut. Res. 2016, 23, 1414-1427. [CrossRef]

13. Saleem, M.H.; Kamran, M.; Zhou, Y.; Parveen, A.; Rehman, M.; Ahmar, S.; Malik, Z.; Mustafa, A.; Ahmad Anjum, R.M.; Wang, B.; et al. Appraising growth, oxidative stress and copper phytoextraction potential of flax (Linum usitatissimum L.) grown in soil differentially spiked with copper. J. Environ. Manag. 2020, 257. [CrossRef]

14. Kabata-Pendias, A. Trace Elements in Soils and Plants, 5th ed.; CRC Press: Boca Ratón, FL, USA, 2011.

15. Yruela, I. Copper in plants: Acquisition, transport and interactions. Funct. Plant Biol. 2009, 36, 409-430. [CrossRef] [PubMed]

16. Zhao, S.; Liu, Q.; Qi, Y.; Duo, L. Responses of root growth and protective enzymes to copper stress in turfgrass. Acta Biol. Crac. Ser. Bot. 2010, 52, 7-11. [CrossRef]

17. Liu, J.; Wang, J.; Lee, S.; Wen, R. Copper-caused oxidative stress triggers the activation of antioxidant enzymes via ZmMPK3 in maize leaves. PLoS ONE 2018, 13, e0203612. [CrossRef]

18. Ku, H.-M.; Tan, C.-W.; Su, Y.-S.; Chiu, C.-Y.; Chen, C.-T.; Jan, F.-J. The effect of water deficit and excess copper on proline metabolism in Nicotiana benthamiana. Biol. Plant. 2011, 56, 337-343. [CrossRef]

19. Monteoliva, M.I.; Rizzi, Y.S.; Cecchini, N.M.; Hajirezaei, M.R.; Alvarez, M.E. Context of action of Proline Dehydrogenase (ProDH) in the Hypersensitive Response of Arabidopsis. BMC Plant Biol. 2014, 14, 21. [CrossRef] [PubMed]

20. Hall, J.L. Cellular mechanisms for heavy metal detoxification and tolerance. J. Exp. Bot. 2002, 53, 1-11. [CrossRef]

21. Emamverdian, A.; Ding, Y.; Mokhberdoran, F.; Xie, Y. Heavy metal stress and some mechanisms of plant defense response. Sci. World J. 2015, 2015, 756120. [CrossRef]

22. Mani, D.; Kumar, C. Biotechnological advances in bioremediation of heavy metals contaminated ecosystems: An overview with special reference to phytoremediation. Int. J. Environ. Sci. Technol. 2014, 11, 843-872. [CrossRef]

23. Carolin, C.F.; Kumar, P.S.; Saravanan, A.; Joshiba, G.J.; Naushad, M. Efficient techniques for the removal of toxic heavy metals from aquatic environment: A review. J. Environ. Chem. Eng. 2017, 5, 2782-2799. [CrossRef]

24. Derwich, E.; Benziane, Z.; Boukir, A. Chemical composition of leaf essential oil of Juniperus phoenicea and evaluation of its antibacterial activity. Int. J. Agric. Biol. 2010, 12, 199-204.

25. Tripathy, V.; Basak, B.B.; Varghese, T.S.; Saha, A. Residues and contaminants in medicinal herbs-A review. Phytochem. Lett. 2015, 14, 67-78. [CrossRef]

26. Clemens, S. Toxic metal accumulation, responses to exposure and mechanisms of tolerance in plants. Biochimie 2006, 88, 1707-1719. [CrossRef]

27. Handique, G.K.; Handique, A.K. Proline accumulation in lemongrass (Cymbopogon flexuosus Stapf.) due to heavy metal stress. J. Environ. Biol. 2009, 30, 299-302.

28. Kováčik, J.; Klejdus, B.; Hedbavny, J.; Štork, F.; Bačkor, M. Comparison of cadmium and copper effect on phenolic metabolism, mineral nutrients and stress-related parameters in Matricaria chamomilla plants. Plant Soil 2009, 320, 231-242. [CrossRef]

29. Ali, I.B.E.; Tajini, F.; Boulila, A.; Jebri, M.A.; Boussaid, M.; Messaoud, C.; Sebaï, H. Bioactive compounds from Tunisian Pelargonium graveolens (L'Hér.) essential oils and extracts: $\alpha$-amylase and acethylcholinesterase inhibitory and antioxidant, antibacterial and phytotoxic activities. Ind. Crops Prod. 2020, 158, 112951. [CrossRef]

30. Fiz, O.; Vargas, P.; Alarcón, M.; Aedo, C.; García, J.L.; Aldasoro, J.J. Phylogeny and historical biogeography of geraniaceae in relation to climate changes and pollination ecology. Syst. Bot. 2008, 33, 326-342. [CrossRef]

31. Ćavar, S.; Maksimović, M.; Vidic, D.; Parić, A. Chemical composition and antioxidant and antimicrobial activity of essential oil of Artemisia annua L. from Bosnia. Ind. Crops Prod. 2012, 37, 479-485. [CrossRef] 
32. Boukhatem, M.N.; Kameli, A.; Saidi, F. Essential oil of Algerian rose-scented geranium (Pelargonium graveolens): Chemical composition and antimicrobial activity against food spoilage pathogens. Food Control 2013, 34, 208-213. [CrossRef]

33. Tahan, F.; Yaman, M. Can the Pelargonium sidoides root extract EPs®7630 prevent asthma attacks during viral infections of the upper respiratory tract in children? Phytomedicine 2013, 20, 148-150. [CrossRef] [PubMed]

34. Moyo, M.; Van Staden, J. Medicinal properties and conservation of Pelargonium sidoides DC. J. Ethnopharmacol. 2014, 152, 243-255. [CrossRef]

35. Colling, J.; Groenewald, J.H.; Makunga, N.P. Genetic alterations for increased coumarin production lead to metabolic changes in the medicinally important Pelargonium sidoides DC (Geraniaceae). Metab. Eng. 2010, 12, 561-572. [CrossRef] [PubMed]

36. Mehrarad, F.; Ziarati, P.; Mousavi, Z. Removing heavy metals from pharmaceutical effluent by Pelargonium grandiflorum. Biomed. Pharmacol. J. 2016, 9, 151-161. [CrossRef]

37. Lam, E.J.; Gálvez, M.E.; Cánovas, M.; Montofré, Í.L.; Keith, B.F. Assessment of the adaptive capacity of plant species in copper mine tailings in arid and semiarid environments. J. Soils Sediments 2018, 18, 2203-2216. [CrossRef]

38. Patel, A.; Patra, D.D. Phytoextraction capacity of Pelargonium graveolens L'Hér. grown on soilamended with tannery sludge-Its effect on the antioxidant activityand oil yield. Ecol. Eng. 2015, 74, 20-27. [CrossRef]

39. Chand, S.; Singh, G.; Rajkumari; Patra, D.D. Performance of rose scented geranium (Pelargonium graveolens) in heavy metal polluted soil vis-à-vis phytoaccumulation of metals. Int. J. Phytoremediat. 2016, 18, 754-760. [CrossRef]

40. Pandey, J.; Chand, S.; Chaurasiya, S.; Kumari, R.; Patra, D.D.; Verma, R.K.; Singh, S. Effect of tannery sludge amendments on the activity of soil enzymes and phytoremediation potential of two economically important cultivars of geranium (Pelargonium graveolens). Soil Sediment Contam. 2019, 28, 395-410. [CrossRef]

41. Dimitrova, M.; Mihaylova, D.; Popova, A.; Alexieva, J.; Tana Sapundzhieva, T.; Fidan, H. Phenolic profile, antibacterial and antioxidant activity of Pelargonium graveolens leaves' extracts. Scientific Bulletin. Ser. F Biotechnol. 2015, 19, 130-135. [CrossRef]

42. El Ouadi, Y.; Bendaif, H.; Mrabti, H.N.; Elmsellem, H.; Kadmi, Y.; Shariati, M.A.; Abdel-Rahman, I.; Hammouti, B.; Bouyanzer, A. Antioxidant activity of phenols and flavonoids contents of aqueous extract of Pelargonium graveolens orgin in the North-East Morocco. J. Microbiol. Biotechnol. Food Sci. 2017, 6, 1218-1220. [CrossRef]

43. Ennaifer, M.; Bouzaiene, T.; Chouaibi, M.; Hamdi, M. Pelargonium graveolens Aqueous Decoction: A New Water-Soluble Polysaccharide and Antioxidant-Rich Extract. Biomed Res. Int. 2018, 2018, 11. [CrossRef]

44. El Aanachi, S.; Gali, L.; Nacer, S.N.; Bensouici, C.; Dari, K.; Aassila, H. Phenolic contents and in vitro investigation of the antioxidant, enzyme inhibitory, photoprotective, and antimicrobial effects of the organic extracts of Pelargonium graveolens growing in Morocco. Biocatal. Agric. Biotechnol. 2020, 29, 101819. [CrossRef]

45. Savvas, D.; Ntatsi, G.; Passam, H.C. The European journal of plant science and biotechnology plant nutrition and physiological disorders in greenhouse grown tomato, pepper and eggplant. Eur. J. Plant Sci. Biotechnol. 2008, 2, $45-61$.

46. Signore, A.; Serio, F.; Santamaria, P. A targeted management of the nutrient solution in a soilless tomato crop according to plant needs. Front. Plant Sci. 2016, 7, 391. [CrossRef]

47. Loreto, F.; Velikova, V. Isoprene produced by leaves protects the photosynthetic apparatus against ozone damage, quenches ozone products, and reduces lipid peroxidation of cellular membranes. Plant Physiol. 2001, 127, 1781-1787. [CrossRef] [PubMed]

48. Martins, L.L.; Mourato, M.P. Effect of excess copper on tomato plants: Growth parameters, enzyme activities, chlorophyll, and mineral content. J. Plant Nutr. 2006, 29, 2179-2198. [CrossRef]

49. Chrysargyris, A.; Papakyriakou, E.; Petropoulos, S.A.; Tzortzakis, N. The combined and single effect of salinity and copper stress on growth and quality of Mentha spicata plants. J. Hazard. Mater. 2019, 368, 584-593. [CrossRef]

50. Reichman, S.M.; Menzies, N.W.; Asher, C.J.; Mulligan, D.R. Responses of four Australian tree species to toxic concentrations of copper in solution culture. J. Plant Nutr. 2006, 29, 1127-1141. [CrossRef]

51. Öquist, G.; Chow, W.S.; Anderson, J.M. Photoinhibition of photosynthesis represents a mechanism for the long-term regulation of photosystem II. Planta 1992, 186, 450-460. [CrossRef]

52. Yruela, I. Copper in plants. Braz. J. Plant Physiol. 2005, 17, 145-156. [CrossRef]

53. Guidi, L.; Lo Piccolo, E.; Landi, M. Chlorophyll fluorescence, photoinhibition and abiotic stress: Does it make any difference the fact to be a C3 or C4 species? Front. Plant Sci. 2019, 10, 174. [CrossRef] [PubMed]

54. Zheng, Y.; Wang, L.; Dixon, M.A. Response to copper toxicity for three ornamental crops in solution culture. HortScience 2004, 39, 1116-1120. [CrossRef]

55. Osmond, C.B.; Grace, S.C. Perspectives of photoinhibition and photorespiration in the field: Quintessential inefficiencies of the light and dark reaction of photosynthesis? J. Exp. Bot. 1995, 46, 1415-1422. [CrossRef]

56. Branco-Neves, S.; Soares, C.; de Sousa, A.; Martins, V.; Azenha, M.; Gerós, H.; Fidalgo, F. An efficient antioxidant system and heavy metal exclusion from leaves make Solanum cheesmaniae more tolerant to $\mathrm{Cu}$ than its cultivated counterpart. Food Energy Secur. 2017, 6, 123-133. [CrossRef]

57. Lange, B.; van der Ent, A.; Baker, A.J.M.; Echevarria, G.; Mahy, G.; Malaisse, F.; Meerts, P.; Pourret, O.; Verbruggen, N.; Faucon, M.P. Copper and cobalt accumulation in plants: A critical assessment of the current state of knowledge. New Phytol. 2017, 213, 537-551. [CrossRef] [PubMed]

58. Tschinkel, P.F.S.; Melo, E.S.P.; Pereira, H.S.; Silva, K.R.N.; Arakaki, D.G.; Lima, N.V.; Fernandes, M.R.; Leite, L.C.S.; Melo, E.S.P.; Melnikov, P.; et al. The hazardous level of heavy metals in different medicinal plants and their decoctions in water: A public health problem in Brazil. BioMed Res. Int. 2020, 2020. [CrossRef] 
59. European Food Safety Authority (EFSA). Review of the existing maximum residue levels for copper compounds according to Article 12 of Regulation (EC) No 396/2005. EFSA J. 2018, 16. [CrossRef]

60. Ghassabzadeh, H.; Mohadespour, A.; Torab-Mostaedi, M.; Zaheri, P.; Maragheh, M.G.; Taheri, H. Adsorption of Ag, Cu and Hg from aqueous solutions using expanded perlite. J. Hazard. Mater. 2010, 177, 950-955. [CrossRef]

61. Matijevic, L.; Romic, D.; Romic, M. Soil organic matter and salinity affect copper bioavailability in root zone and uptake by Vicia faba L. plants. Environ. Geochem. Health 2014, 36, 883-896. [CrossRef]

62. Eskandari, S.; Mozaffari, V. Interactive effect of soil salinity and copper application on growth and chemical composition of pistachio seedlings (cv. Badami). Commun. Soil Sci. Plant Anal. 2014, 45, 688-702. [CrossRef]

63. Li, L.; Long, M.; Islam, F.; Farooq, M.A.; Wang, J.; Mwamba, T.M.; Shou, J.; Zhou, W. Synergistic effects of chromium and copper on photosynthetic inhibition, subcellular distribution, and related gene expression in Brassica napus cultivars. Environ. Sci. Pollut. Res. 2019, 26, 11827-11845. [CrossRef] [PubMed]

64. Chrysargyris, A.; Antoniou, O.; Tzionis, A.; Prasad, M.; Tzortzakis, N. Alternative soilless media using olive-mill and paper waste for growing ornamental plants. Environ. Sci. Pollut. Res. 2018, 25, 35915-35927. [CrossRef] [PubMed]

65. Tzortzakis, N.G.; Economakis, C.D. Shredded maize stems as an alternative substrate medium: Effect on growth, flowering and yield of tomato in soilless culture. J. Veg. Sci. 2005, 11, 57-70. [CrossRef]

66. Chrysargyris, A.; Antoniou, O.; Athinodorou, F.; Vassiliou, R.; Papadaki, A.; Tzortzakis, N. Deployment of olive-stone waste as a substitute growing medium component for Brassica seedling production in nurseries. Environ. Sci. Pollut. Res. $2019,26$. [CrossRef] [PubMed]

67. Chrysargyris, A.; Laoutari, S.; Litskas, V.D.; Stavrinides, M.C.; Tzortzakis, N. Effects of water stress on lavender and sage biomass production, essential oil composition and biocidal properties against Tetranychus urticae (Koch). Sci. Hortic. 2016, 213, 96-103. [CrossRef]

68. Wojdyło, A.; Oszmiański, J.; Czemerys, R. Antioxidant activity and phenolic compounds in 32 selected herbs. Food Chem. 2007, 105, 940-949. [CrossRef]

69. Tzortzakis, N.G.; Tzanakaki, K.; Economakis, C.D. Effect of origanum oil and vinegar on the maintenance of postharvest quality of tomato. Food Nutr. Sci. 2011, 2, 974-982. [CrossRef]

70. Meyers, K.J.; Watkins, C.B.; Pritts, M.P.; Liu, R.H. Antioxidant and antiproliferative activities of strawberries. J. Agric. Food Chem. 2003, 51, 6887-6892. [CrossRef]

71. De Azevedo Neto, A.D.; Prisco, J.T.; Enéas-Filho, J.; De Abreu, C.E.B.; Gomes-Filho, E. Effect of salt stress on antioxidative enzymes and lipid peroxidation in leaves and roots of salt-tolerant and salt-sensitive maize genotypes. Environ. Exp. Bot. 2006, 56, 87-94. [CrossRef]

72. Benimeli, C.S.; Medina, A.; Navarro, C.M.; Medina, R.B.; Amoroso, M.J.; Gómez, M.I. Bioaccumulation of copper by Zea mays: Impact on root, shoot and leaf growth. Water Air Soil Pollut. 2010, 210, 365-370. [CrossRef]

73. Azooz, M.M.; Abou-Elhamd, M.F.; Al-Fredan, M.A. Biphasic effect of copper on growth, proline, lipid peroxidation and antioxidant enzyme activities of wheat (Triticum aestivum cv. Hasaawi) at early growing stage. Aust. J. Crop Sci. 2012, 6, 688-694. 